\title{
Broadband internet availability and establishments' employment growth in Germany: evidence from instrumental variables estimations
}

\author{
Bastian Stockinger ${ }^{*}$ (D)
}

\begin{abstract}
This study investigates the effect of broadband internet availability on German establishments' employment growth. The database used is a random sample of business establishments, augmented by the local availability of broadband. The observation period is 2005-2010, when broadband was introduced in rural regions of Western Germany and in large parts of Eastern Germany. For the Western German subsample, technical frictions in broadband rollout are exploited to obtain exogenous variation in broadband availability. The findings indicate a negative (albeit not very robust) employment growth effect of broadband availability for Western German manufacturers, and a robustly positive effect for Western German service establishments, including most knowledge-intensive industries. For Eastern Germany, a similar identification strategy is potentially available, but turns out invalid in this particular setting. An alternative identification approach (a long difference model) indicates positive employment growth effects in both sectors for Eastern Germany. Overall, the findings suggest that broadband expansion has helped create jobs in firms which use broadband intensely.
\end{abstract}

Keywords: Labor demand, Employment growth, Broadband internet, Technological change, Regional labor markets JEL Classification: J23, O33, R23

\section{Introduction}

The expansion of broadband internet is one of the most important current developments in the technological infrastructure of industrialized countries. Across the globe, national and regional governments are investing large sums in broadband expansion, notably to rural areas. Germany, the empirical focus of this paper, is no exception. According to one estimate, the German federal government's goal to provide download rates of at least $50 \mathrm{Mbit} / \mathrm{s}$ to all households in Germany by 2018 requires investments of at least $€ 20$ billion. ${ }^{1}$ One of the declared goals of broadband expansion is job creation, particularly in knowledge-intensive industries. As yet, however, empirical evidence concerning firms' job creation is sparse and ambiguous.

Theoretically, broadband may affect the labor market through various channels and in various directions. For instance, broadband might increase the demand for products sold via the internet (cf. Brynjolfsson et al. 2009; Goolsbee 2000; Ellison and Ellison 2009; Goolsbee
*Correspondence: bastian.stockinger@iab.de

Institute for Employment Research (IAB), Regensburger Str. 104, 90478 Nuremberg, Germany

\footnotetext{
${ }^{1}$ As of mid-2018, 82.9 percent of all German households could receive broadband access with $50 \mathrm{Mb} / \mathrm{s}$ speed (Federal Ministry of Transport and Digital Infrastructure 2018). See also https://www.it-zoom.de/it-director/e/breit bandversorgung-in-deutschland-9341/, last accessed April 28, 2016. The federal state of Bavaria alone contributes $€ 1.5$ bn to reach this goal within its territory (see http://www.schnelles-internet-in-bayern.de/foerderung/ueberblick .html, last accessed April 28, 2016).
} 
et al. 2010; Einav et al. 2014), with theoretically ambiguous implications for employment in online retail and stationary retail. Another channel could be labor supply and matching effects working through a more efficient job search (e.g., Autor 2001; Kuhn and Skuterud 2004). In contrast, this study seeks to isolate the employment growth effects of broadband expansion at the establishment level. Furthermore, the study addresses effect heterogeneity between sectors and on knowledge-intensive industries in particular, to obtain a clearer impression of the channels through which broadband may affect establishments' employment growth.

The analysis focuses on the years 2005-2010, when broadband was introduced in the rural parts of Western Germany and large parts of Eastern Germany. For the Western German subsample, in order to identify the causal relationship between broadband availability and employment growth, the analysis uses exogenous differences in local broadband availability arising from historically determined technical frictions. For Eastern Germany, a similar identification approach is potentially available, but it turns out inadequate in the current setting.

With regard to the data and identification approaches, two major limitations of this study should be stated clearly. First, the analysis is based on first-generation broadband, i.e., the technological standard of the early 2000s, which enabled relatively simple applications such as e-mail and lower-resolution video streaming. Today, the term "broadband" may refer to much higher bandwidths and much more demanding applications, the labor market effects of which may differ from those found in this paper. Second, the main identification strategy applies only to rural Western Germany, and therefore does not capture the bulk of economic activity in the country. However, rural regions are often the focus of public debates and policies on infrastructure improvement. In this sense, this study might still contribute policy-relevant insights.

The remainder of this paper is structured as follows. Section 2 sketches potential labor market effects of information and communication technology (ICT) and broadband internet and reviews previous empirical evidence. Section 3 describes the broadband data and discusses the identification strategy. Section 4 presents the estimated model of employment growth, the employment data, and descriptive statistics. Section 5 presents the estimation results. Section 6 concludes.

\section{Broadband and the labor market: previous research}

In the terminology of Bresnahan and Trajtenberg (1995), information and communication technologies (ICTs), and therefore broadband, are "general purpose technologies" which improve the conditions for innovation and productivity in a broad range of economic activities, that is, far beyond the ICT sector (see also Harris 1998 and Atkinson and McKay 2007). Accordingly, empirical studies typically find positive effects of advancements in ICT on output, growth, and productivity, see for instance Holt and Jamison (2009) for evidence from the US, and Czernich et al. (2011) for cross-country evidence. Regarding the effects of broadband in particular, see Cardona et al. (2013), Bertschek et al. (2015), De Stefano et al. (2018), Draca et al. (2018), and Haller and Lyons (2019). Regarding the labor market, the absolute employment effect of technological progress is theoretically ambiguous. Generally speaking, a given technology may substitute for or complement labor, depending on the particular economic activity (industry) and configuration of work tasks (occupation), see e.g. Cahuc and Zylberberg (2004, p. 587 sqq.).

Broadband in particular may affect both the supply and demand sides of the labor market: On the one hand, fast internet connections facilitate job search and may increase the number and quality of job offers job seekers can receive, thus improving the conditions for labor supply and worker-firm matching (see, e.g., Autor 2001; Kuhn and Skuterud 2004; Kuhn and Mansour 2014; and Mang 2012). On the other hand, broadband may affect labor demand through its use in the production process. By increasing the efficiency of information-intensive production processes (and service provision), broadband allows for productivity growth and process innovations, at least in particular industries. These considerations emphasize the importance of industrial heterogeneity, pointing to knowledge- and information-intensive industries as being particularly affected by broadband expansion. Furthermore, there are a number of secondary channels through which broadband potentially affects firm-level employment. For instance, a fast internet connection may facilitate outsourcing and offshoring of knowledge-intensive services (Katz and Suter 2009), thereby potentially destroying jobs within the outsourcing firm and creating jobs elsewhere. Furthermore, broadband facilitates working from home (Dettling 2017) and more generally, reconciling employment and family life (Billari et al. 2019). By using data on establishments' local broadband availability, this study captures both labor demand and labor supply effects. Due to the focus on establishment locations, labor demand appears theoretically as the more obvious channel of effects. Empirically, however, it is not possible to isolate the demand- and supply-side channels (unless workers' and firms' broadband availability can be distinguished precisely, which is not possible with the data used in this study). 
Many previous empirical studies on the labor market effects of broadband consider outcomes at the regional level, since broadband availability varies mainly in the spatial dimension. Overall, studies at the regional level tend to find positive, but not necessarily large employment and wage effects of broadband, with high-skilled workers and service firms being most likely to benefit (see What Works Centre for Local Economic Growth 2015, for a comprehensive literature survey). Similarly, Bertschek et al. (2015) conclude that the overall labor market effects of broadband tend to be positive. Most empirical studies focus on the US; among these, some consider employment growth as an outcome. Forman et al. (2012) find that firms' investment in advanced internet technology increases employment growth in US counties, but only in a small subset of already technologically advanced counties. Kolko (2012) finds for US counties and ZIP code areas that the number of broadband providers increases employment growth, mostly in technology-intensive sectors (e.g., scientific and technical services). Whitacre et al. (2014) find that rural US counties with higher levels of broadband adoption experience higher employment growth. Ivus and Boland (2015) study the effect of broadband availability on employment growth in Canadian regions. They find no significant overall effect, but a positive effect for rural areas, stemming from the service sector and from ITintense industries in particular. Atasoy (2013) finds that local broadband availability increases employment in US counties, an effect driven by the expansion of incumbent firms rather than firm entry. Using German data, Fabritz (2013) finds evidence of small positive employment effects of broadband availability at the municipality level, apparently driven by the service sector.

Turning to firm-level evidence, there are several studies that observe not only broadband availability, but also the actual adoption (use) of broadband. Overall, empirical studies tend to find stronger and more robust effects of broadband adoption as compared to availability. For instance, Bertschek et al. (2013) find that broadband adoption positively affects innovation in German firms. Colombo et al. (2013) find positive productivity effects associated with the adoption of advanced broadband technology by Italian firms. Bertschek and Niebel (2016) find evidence of positive labor productivity effects of mobile internet use by German firms, supposedly working through increased flexibility in the organization of work. In contrast, De Stefano et al. (2014) find no significant effect of broadband adoption on the sales, employment, labor productivity, or survival of firms in the UK. Canzian et al. (2015) find a positive effect of an advanced broadband technology (ADSL2+) on Italian firms' productivity, but not employment; however, they observe only availability, but not adoption. Broadly speaking, service-sector employment seems to be more strongly affected by broadband than manufacturing employment, likely reflecting the key role of information as an input in services (Arntz et al. 2016).

Considering effect heterogeneity at the firm and worker levels, Akerman et al. (2015) find that broadband adoption increased high-skilled workers' employment, productivity, and wages, at the expense of low-skilled workers, in Norway. They attribute their findings to the complementarity of internet use with abstract, nonroutine work tasks. In contrast, Akerman et al. (2015) find no effect on the output elasticity of capital, suggesting that broadband affects labor demand primarily through its effect on labor productivity. Furthermore, the authors rule out several alternative channels through which broadband expansion might affect labor market outcomes, such as a shift in product demand to products that can be ordered online. Since the results are found not to be driven by such alternative explanations, it is argued that the complementarity between broadband and (skilled) labor, and therefore the productive use of broadband, is the main channel of effects.

Against this background of previous research, this study seeks to contribute evidence on the employment growth effects of broadband availability at the establishment level, using German data, and thereby to fill an empirical research gap.

\section{Identification strategy}

\subsection{Broadband data}

This paper focuses on the first generation of broadband, which became available in Germany around the year 2000. By far the most important broadband technology in Germany was and is DSL (digital subscriber line), which accounts for over 90 percent of broadband subscriptions (Bundesnetzagentur 2013). Compared to older technologies (dial-up, ISDN), DSL drastically increased data transfer rates (from at most $128 \mathrm{~kb} / \mathrm{s}$ to at least $384 \mathrm{~kb} / \mathrm{s}$ ). The main explanatory variable in this paper is DSL availability. It is measured as the share of households, at the municipality-year level, for which a DSL connection is technically available, but not necessarily adopted (used). The data are obtained from the Broadband Atlas Germany (Federal Ministry of Economics and Technology 2009).

First-generation DSL was rolled out rather rapidly in Germany, because it was based on the telephone network-that is, an existing infrastructure. Figure 4 in "Appendix" illustrates that overall, Germany reached a high level of DSL availability within the period of observation. As illustrated by Fig. 1, the largest cities (e.g. 


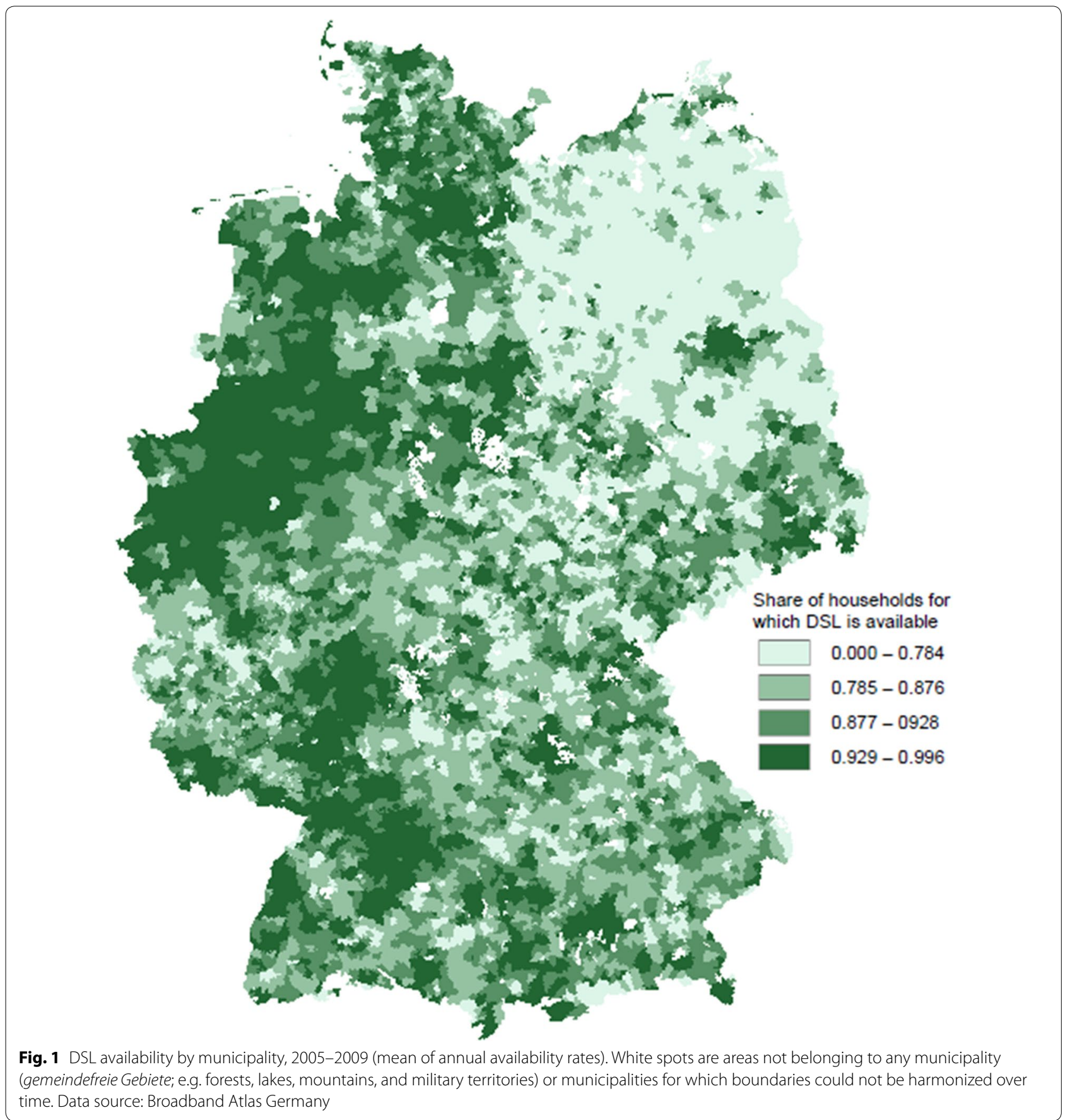

Berlin, Hamburg, Munich, and the Rhein-Ruhr area) were well served with DSL throughout this period. In contrast, a large number of municipalities in rural Western Germany and Eastern Germany gained DSL access only in this period. More precisely, there are considerable differences even between neighbor municipalities that do not differ much in other respects.
These sharp differences in DSL expansion between municipalities offer an opportunity to identify causal relationships between local broadband availability and labor market outcomes, even though broadband is provided by private firms and therefore, local broadband availability should be endogenous with regard to economic outcomes. However, by relying on the preinstalled telephone network, there were some unforeseen 
and therefore quasi-random technical obstacles to DSL provision in some municipalities. These technical obstacles have been exploited by Czernich et al. (2011), Falck et al. (2014), Bauernschuster et al. (2014), and others to construct instrumental variables (IVs). This study applies a similar IV approach, yet with the focus on German establishments' labor demand, an outcome previously not addressed in the empirical literature.

\subsection{Instrumental variable approach}

To identify the causal relationship between DSL availability and employment growth, this study seeks to exploit sources of exogenous variation in the former variable. There exist two such sources, one each for rural Western Germany and urban Eastern Germany, which potentially allow for the construction of instrumental variables.

Turning first to Western Germany, the key to the identification strategy is that during the observation period of this study, DSL was supplied using "fiber-to-the-node" (FTTN) technology. This means that only the more central part of the telecommunications network was already equipped with "fast" fiber wires. In contrast, the decentral part of the network (the "last mile"), which reaches from the so-called main distribution frames (MDFs) to the households, was still served via copper wires. The telephone network, including the MDFs, was installed in the 1960s by the (West) German Federal Postal Services, then the state-owned monopoly provider of telephone service. The Federal Postal Services, not subject to competition and not profit-oriented, installed the network such that telephone service could be provided universally throughout Germany. The location of the MDFs was determined by the availability of lots or buildings were they could be placed (cf. Falck et al. 2014). Most importantly, the precise locations of MDFs were irrelevant for the feasibility and quality of telephone service, and even pre-DSL internet service (dial-up and ISDN). Thus, MDF locations were determined quasi-randomly at a small spatial scale, in the sense that it did not matter whether a MDF was some kilometers closer or further away from its users. Therefore, it is rather unlikely that MDF locations, chosen in the 1960s, are correlated with local amenities and services-e.g., closeness to town centers, public transport stations, or centers of economic activity (such as shopping centers and industrial districts) - that could matter for employment (let alone employment growth) in the 2000s.

To provide some descriptive evidence, the circa 8000 MDFs were allocated relatively densely and evenly across the country (see Fig. 5 in "Appendix"), especially in rural areas. As indicated by Fig. 6 in "Appendix", municipalities above and below the distance threshold are frequently located right next to each other, and therefore likely very similar. Furthermore, there are very few municipalities whose entire territory is more than $4.2 \mathrm{~km}$ distant from the MDF (cf. Fig. 3 in Sect. 5.2), due to the dense allocation of MDFs even in the most rural areas. Finally, some municipalities got connected to a rather far-away MDF (more than $4.2 \mathrm{~km}$ from the centroid) even though there is a closer MDF (less than $4.2 \mathrm{~km}$ from the centroid). This would not probably not have happened had distance played any important role for telephone service.

With the introduction of broadband internet, however, distance to the MDF suddenly became important. When DSL was introduced in the 2000s, the main provider (Deutsche Telekom) defined the minimum signal strength required for DSL service to be $55 \mathrm{~dB}$, which translates into a copper-wire distance of approximately $4.2 \mathrm{~km}$. Thus, beyond $4.2 \mathrm{~km}$ from the MDF, Deutsche Telekom did not provide DSL until, years later, at least part of the copper wires became replaced by fiber wires. Other providers had to rely on the same network and therefore could not provide DSL either. Although it would have been technically possible for Deutsche Telekom to create additional MDFs, this did not happen: DSL was rolled out in the early 2000 s purely using the thenexisting telephone network, supposedly for economic reasons-installing new wires would have been very costly, since telecommunication wires are installed subsurface in Germany (see also Falck et al. 2014).

The $4.2 \mathrm{~km}$ distance threshold can therefore be used as a binary IV for local broadband availability. To obtain an unambiguous measure of the distance between a municipality and its MDF, one can use the centroid (geographic center) of the municipality. Thus, the following IV is defined for each municipality $m$ :

$$
I V_{m}=\left\{\begin{array}{c}
1 \text { if municipality centroid }>4.2 \mathrm{~km} \text { from assigned } M D F \\
0 \text { otherwise. }
\end{array}\right.
$$

Municipalities with $I V_{m}=1$ are thus expected to have a lower DSL availability.

For this dummy variable to be a valid instrument, it must not affect labor market outcomes except through its effect on DSL availability. One should therefore ask whether the location of economic activity (i.e., firm location) depends on the nearby presence of an MDF, at least concerning firms whose business strongly depends on fast internet access. In the rural (Western German) setting which this study focuses on, this might be less of a concern, given that information-intensive economic activities tend to concentrate in urban areas. Nevertheless, to alleviate potential problems of endogenous firm location, in this study the Western sample is restricted to establishments founded before the observation period (2005-2010). For these establishments, DSL availability can plausibly be regarded as given, and hence their 


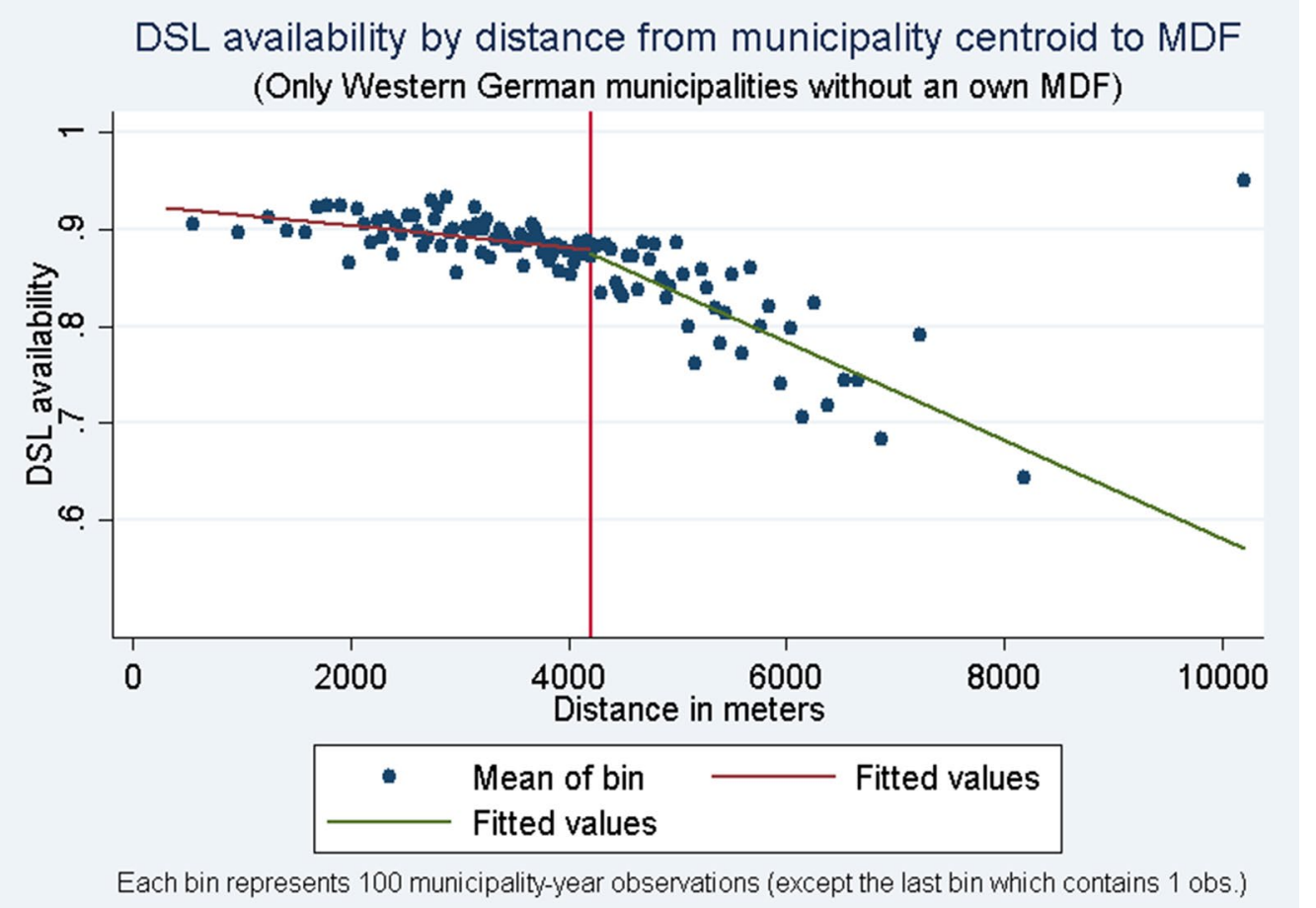

Fig. 2 Relevance of the IV. Data sources: Broadband Altas Germany, Deutsche Telekom

locations can be regarded as exogenous. A technical prerequisite of this IV approach, and its main caveat, is that it only applies to municipalities without an own MDF, which are rather rural. More urban municipalities have at least one own MDF, so the distance between the municipality centroid and the MDF is ambiguous. These municipalities are therefore excluded from the sample.

Deviating slightly from Falck et al. (2014), the identification strategy in this study focuses on the distance between each municipality and its originally assigned MDF (i.e., the MDF to which the municipality's households were connected for telephone service in the 1960s). For a minor share of municipalities with an assigned MDF above the threshold, this distance was in fact not an obstacle to DSL rollout, namely if there was another, nearer MDF than the originally assigned one. These municipalities could, after all, obtain DSL by getting connected to the nearer MDF. Falck et al. (2014) exploit this setting to construct a second IV, namely another distance-threshold dummy with respect to the nearest MDF, given that the originally assigned MDF's distance is above the threshold. However, this results in an even smaller and more rural subsample of municipalities. Given the aim of this study (identifying establishmentlevel employment growth effects), such a subsample seems too small and selective, considering that establishments and employment concentrate in more urban areas.
Therefore, only the first distance threshold (referring to the originally assigned MDF) is used to create an IV, and the (few) municipalities above this threshold, but within reach of a nearer MDF, are dropped from the sample. For a descriptive comparison of sample municipalities to all other municipalities, see Table 13 in "Appendix".

The relevance of the instrument can be displayed as a relationship between municipal DSL availability (in year t) and the distance to the municipality's MDF. In Fig. 2, municipality-year observations are grouped into bins (each containing 100 observations, except for the last bin) ordered form nearest to furthest from the MDF. As the graph shows, DSL availability decreases sharply at the $4.2 \mathrm{~km}$ threshold. The last bin (at $>10,000$ meters from the MDF) contains only one observation and therefore can be regarded as an outlier.

In Eastern Germany (the former German Democratic Republic), there was another historic "accident" that also caused some municipalities to receive DSL service much later than others, namely the installation of the so-called OPAL (optical access line) technology in the early 1990s (see Falck et al. 2014 and Fig. 5 in "Appendix"). Although OPAL was considered state-of-the-art at the time, the technology was incompatible with broadband, and thus turned out to be a disadvantage for DSL rollout. Therefore, analogous to the distance threshold used for Western German municipalities, a municipal-level OPAL 
dummy could be used to split the sample into a technologically disadvantaged group and a "lucky" group of municipalities. However, descriptive statistics indicate that the OPAL dummy is correlated with municipalities' labor market indicators, which might directly affect establishments' employment growth. It is therefore not a valid IV for DSL availability in the present context (unlike in the case of Falck et al. (2014), where the outcome of interest is voting behavior). Therefore, in the following, only the IV approach for Western Germany is pursued.

\subsection{Measurement and identification}

Besides the above-discussed problem of endogeneity (the main motivation for the proposed IV approach), another rationale for employing IV regression is to address measurement error in the explanatory variable (see Angrist and Pischke 2009, p. 127 sqq. and Hausman 2001), which biases OLS estimates towards zero. Here, the main source of measurement error is that DSL availability is observed only at the municipality level, while employment growth is observed at the establishment level. By using variation in DSL availability driven by the instruments, attenuation bias can be alleviated. However, there is also measurement error in the instruments themselves, namely if a municipality is classified as being above the distance threshold, while the establishment location is in fact below the threshold, or vice versa. Yet, this problem can be addressed by using alternative instruments (see robustness checks).

Regarding the interpretation of the estimates, the IV estimator identifies the local average treatment effect (LATE) for "compliers" (Angrist and Pischke 2009, p. 154 sq.). In this context, compliers are establishments in municipalities which have lower (higher) broadband availability if the technical friction used as an IV is (not) in place (Imbens and Angrist 1994). Considering the massive negative association between the IV and municipal broadband availability (see also descriptive statistics below), non-compliance appears to be a negligible problem. Municipalities could hardly circumvent the technical obstacle from which the IV is constructed, particularly not within a few years. At the establishment level, one potential problem of non-compliance does arise: Large customers can obtain broadband service independently of the municipality-wide DSL provision, via private leased lines. Yet, leased lines are affordable only to larger establishments. According to Fabritz (2013), 82 percent of German establishments use the local DSL infrastructure. This share is likely to be even higher in the sample at hand, which omits urban Western Germany and therefore the bulk of Germany's large establishments (the average size of the sample establishments is about ten full-time employees). Thus, only few establishments in the sample are likely to be non-compliers.
Another caveat regarding the interpretation of the estimates is that only the availability, but not the adoption of broadband is observed. As discussed by Czernich (2014), the effects of broadband availability are necessarily closer to zero than the effects of its adoption if, as seems likely, broadband affects firms through its actual use by firms. At the same time, however, note that the observation period captures a relatively late stage of DSL rollout (the late-coming municipalities), when the DSL technology was already well established and easily affordable even to households. Most establishments therefore likely adopted DSL as soon as it became available, so the difference between availability and adoption should be small, and the estimated effects of DSL availability should largely reflect the effects of DSL adoption.

\section{Employment data, estimation model, and sample}

The broadband data are merged with employment data from the Establishment History Panel (BHP, version 1975-2010) of the Institute for Employment Research (IAB) at the municipality-year level. ${ }^{2}$ The BHP is an annual panel, based on administrative records, that contains employment aggregates and other characteristics of all establishments in Germany with at least one employee liable to social security at the reference date, June 30. For a more detailed description of the BHP, see Gruhl et al. (2012). The base sample used is a ten percent random sample of establishments observed in the BHP in the period 2005-2010. This sample is cleared further of establishments in Western German municipalities where the IV approach cannot be applied (i.e. municipalities with one or several own MDF(s)). Furthermore, the sample is cleared of establishments observed for the first time in 2005 or later, since these are newly founded establishments which may have chosen their location conditional on broadband availability. All further sample cleaning steps are documented in "Appendix" section "Sample restrictions". After all sampling and cleaning steps, there remain 33,473 observations of 8405 establishments, where 56 percent of observations (57 percent of establishments) belong to the service sector.

The estimation equation for establishments' employment growth can be expressed as follows:

$$
\begin{aligned}
\ln \left(\frac{L_{i t+1}}{L_{i t}}\right)= & \beta_{0}+\beta_{1} D S L_{m t}+\boldsymbol{\beta}_{2} \boldsymbol{X}_{i \boldsymbol{t}}+\boldsymbol{\beta}_{3} \boldsymbol{X}_{\boldsymbol{m} \boldsymbol{t}}^{\prime} \\
& +\theta_{c}+\vartheta_{j}+\mu_{t}+\varepsilon_{i t} .
\end{aligned}
$$

${ }^{2}$ Municipality codes refer to territorial boundaries as of Dec. 31, 2008. As municipality borders change over time, the municipality codes had to be harmonized to the 2008 state in both the broadband and the BHP data. This harmonization was done independently for the two datasets. As a result, for a small share of the BHP observations (0.4 percent, measured at the municipality-year level), the broadband data could not be merged. 
For the Western German sample, the specification is a two-stage model, with Eq. (1) being the second stage and $D S L_{m t}$ being instrumented in the following first-stage equation:

$$
\begin{aligned}
D S L_{m t}= & \alpha_{0}+\alpha_{1} I V_{m}+\boldsymbol{\alpha}_{2} \boldsymbol{X}_{\boldsymbol{i} \boldsymbol{t}}+\boldsymbol{\alpha}_{3} \boldsymbol{X}^{\prime}{ }_{\boldsymbol{m} \boldsymbol{t}} \\
& +\pi_{c}+\rho_{j}+\sigma_{t}+u_{m t} .
\end{aligned}
$$

For the Eastern German sample, Eq. (1) is estimated in one step using OLS. The dependent variable in all estimations is the $\log$ growth rate of establishment $i$ 's employment $\left(L_{i t}\right)$ between years $t+1$ and $t$ (with $t \in[2005,2009])$. The explanatory variable of interest is the availability of broadband in municipality $m$ and year $t\left(D S L_{m t}\right)$, measured as the share of households for which DSL is available. Since broadband availability is measured at the municipality level, and the sampled municipalities are relatively small, places of work and residence are relatively unlikely to coincide. That is, the estimate $\widehat{\beta}_{1}$ should be driven primarily by the productive use of broadband in establishments, rather than by potential effects on workers' job search behavior, worker-firm matching, or product demand. However, as discussed in Sect. 2, it is not possible with the data at hand to isolate labor demand and supply effects.

Control variables at the establishment level $\left(X_{i t}\right)$ are the $\log$ number of full-time employees, the share of high-qualified employees, ${ }^{3}$ the log median wage of fulltime employees, and three dummies for establishment age. Unfortunately, the BHP does not contain data on capital, investment, output, or profitability. Municipalitylevel controls $\left(X_{m t}^{\prime}\right)$ include log full-time employment and its growth rate (between $t-1$ and $t$ ), log full-time employment density, the share of high-qualified employment, as well as the log mean wage of full-time employees. Municipality-level controls are computed using the entire population of establishments in the BHP. The mean wage is computed as the municipality-year mean of establishment-level median wages. Finally, fixed effects for districts $(c)$, three-digit industries $(j)$, and years $(t)$ are included.

Since large establishments are rare but employ a major share of the total workforce, all estimations are weighted by the establishments' full-time employment, to obtain meaningful estimates regarding the overall employment growth effect (unweighted regressions are also presented as a robustness check). Furthermore, standard errors are

\footnotetext{
${ }^{3}$ High-qualified employees are defined by their occupation rather than education, because the latter variable has a large number of missing values. Occupations considered as high-qualified are: engineers, managers, professionals (e.g. lawyers, architects), semi-professionals (service-sector workers with an advanced qualification), and technicians (manufacturing-sector workers with an advanced qualification).
}

\begin{tabular}{|c|c|c|c|}
\hline & \multicolumn{2}{|c|}{ Western Germany } & \multirow[t]{2}{*}{ Eastern Germany } \\
\hline & $\mathrm{IV}=0$ & $\mathrm{IV}=1$ & \\
\hline $\begin{array}{l}\text { Municipality-year } \\
\text { obs. }\end{array}$ & $6820(62.6 \%)$ & 4081 (37.4\%) & 9602 \\
\hline Municipalities & $1482(62.4 \%)$ & $893(37.6 \%)$ & 2085 \\
\hline $\begin{array}{l}\text { Establishment-year } \\
\text { obs. }\end{array}$ & 21,708 (64.9\%) & $11,765(35.1 \%)$ & 78,354 \\
\hline Establishments & 5449 (64.8\%) & 2956 (35.2\%) & 19,758 \\
\hline $\begin{array}{l}\text { Mean DSL } \\
\text { availability }^{\text {a }}\end{array}$ & 0.893 & 0.817 & 0.742 \\
\hline
\end{tabular}

Table 1 Sample overview

a Measured at the municipality-year level. Data sources: Broadband Atlas Germany, Deutsche Telekom, BHP 7510

clustered at the municipality level, since this is the level at which the instrument varies.

The final estimation samples contain 33,473 establishment-year observations from 2375 municipalities for Western Germany and 78,354 observations from 2085 municipalities for Eastern Germany (see Table 1). The striking discrepancy between the East and West sample sizes is due to the rural bias of the Western subsample, owing to the restriction that sample municipalities must not possess an own MDF (see Sect. 3.2). In the Western sample, 35 percent of the establishments are subject to a local technical obstacle impeding DSL rollout (i.e. $I V_{m}=1$ ), and DSL availability is significantly lower in these municipalities. For further summary statistics at the establishment and municipality levels, see Tables 11 and 12 in "Appendix".

Regarding the validity of the identification strategy, the key question is whether the IV can be regarded as exogenous. For a basic assessment of exogeneity, we can compare means of relevant pre-determined covariates for both values of the IV (Table 2). The data refer to 1999, the year before DSL was introduced, so DSL availability cannot have affected these values. The two middle columns contain raw means of the respective variable; the reported $\mathrm{p}$-values stem from $\mathrm{t}$-tests on equality of means, where means were cleared of district fixed effects, analogous to the estimation equation.

The table indicates for Western Germany that municipalities above the distance threshold had slightly lower employment levels in 1999 than municipalities below the threshold. However, there are no significant differences in past employment growth and local labor market characteristics such as the share of high-qualified workers and the wage level. This slight imbalance is accounted for in the estimations by controlling for the contemporary values of the same covariates. For Eastern Germany, in contrast, splitting municipalities by the value of the OPAL 
Table 2 Covariate balance (data for 1999)

\begin{tabular}{|c|c|c|c|}
\hline Western Germany & $\begin{array}{l}\text { Above threshold } \\
(\mathrm{IV}=1)\end{array}$ & Below threshold $(\mathrm{IV}=0)$ & $p$ value $^{a}$ \\
\hline Log full-time employment growth rate & 0.043 & 0.041 & 0.729 \\
\hline Log full-time employment & 5.091 & 5.203 & $0.077^{*}$ \\
\hline Log mean wage & 4.370 & 4.384 & 0.448 \\
\hline Share high-skilled (occupation) & 0.102 & 0.111 & 0.182 \\
\hline Share high-qual. (education) & 0.027 & 0.031 & 0.584 \\
\hline Eastern Germany & OPAL area & Non-OPAL area & p-value ${ }^{a}$ \\
\hline Log full-time employment growth rate & 0.019 & 0.003 & $0.026^{* *}$ \\
\hline Log full-time employment & 6.565 & 6.175 & $0.006^{* * *}$ \\
\hline Log mean wage & 4.112 & 4.093 & 0.307 \\
\hline Share high-skilled (occupation) & 0.148 & 0.141 & 0.797 \\
\hline Share high-qual. (education) & 0.066 & 0.061 & 0.351 \\
\hline
\end{tabular}

${ }^{a}$ From a t-test on equality of means cleared of district fixed effects. Data sources: Deutsche Telekom, BHP 7510

${ }^{*} \mathrm{p}<0.1,{ }^{* *} \mathrm{p}<0.05,{ }^{* *} \mathrm{p}<0.01$

Table 3 OLS estimates, Western Germany

\begin{tabular}{|c|c|c|c|c|}
\hline Log employment growth rate & Manufacturing & & Services & \\
\hline DSL availability & $-0.028(-1.373)$ & $0.004(0.177)$ & $0.009(0.342)$ & $0.045(1.613)$ \\
\hline Log full-time employment, est. & $0.005(2.042)^{* *}$ & $-0.004(-1.597)$ & $\begin{array}{l}0.001 \\
(0.434)\end{array}$ & $\begin{array}{l}-0.001 \\
(-0.595)\end{array}$ \\
\hline Log median full-time wage, est. & $0.008(0.647)$ & $0.051(4.469)^{* * *}$ & $0.012(1.487)$ & $0.015(2.569)^{* *}$ \\
\hline Young establishment (<5 years) & $0.004(0.352)$ & $-0.010(-0.997)$ & $0.035(4.271)^{* * *}$ & $0.023(1.932)^{*}$ \\
\hline Mid-age establishment (5-14 years) & $0.002(0.215)$ & $-0.006(-0.946)$ & $0.014(1.987)^{* *}$ & $0.007(1.344)$ \\
\hline Share high-skilled & $0.060(2.024)^{* *}$ & $0.074(2.681)^{* * *}$ & $0.017(1.278)$ & $0.014(1.115)$ \\
\hline Log full-time employment, mun. & $0.003(0.989)$ & $0.004(1.165)$ & $0.000(0.038)$ & $-0.004(-1.018)$ \\
\hline Log full-time empl. density, mun. & $-0.009(-2.407)^{* *}$ & $-0.011(-2.598)^{* * *}$ & $-0.017(-3.175)^{* * *}$ & $-0.008(-2.004)^{* *}$ \\
\hline Log mean full-time wage, mun. & $0.016(0.643)$ & $0.013(0.637)$ & $0.083(1.699)^{*}$ & $0.097(2.241)^{* *}$ \\
\hline Log full-time empl. growth rate, mun. & $0.036(1.273)$ & $-0.013(-0.540)$ & $0.016(0.221)$ & $0.009(0.120)$ \\
\hline Share high-skilled, municipality & $-0.067(-1.470)$ & $0.017(0.433)$ & $-0.038(-0.592)$ & $-0.014(-0.357)$ \\
\hline Year FE & & Yes & & Yes \\
\hline Industry FE (3-digit) & & Yes & & Yes \\
\hline District FE & & Yes & & Yes \\
\hline Observations & 14,823 & 14,823 & 18,650 & 18,650 \\
\hline Adjusted $R^{2}$ & 0.008 & 0.065 & 0.011 & 0.056 \\
\hline
\end{tabular}

t statistics in parentheses. ${ }^{*} \mathrm{p}<0.10,{ }^{* *} \mathrm{p}<0.05,{ }^{* * *} \mathrm{p}<0.01$. All estimations weighted by full-time employment. Constant omitted from output. Standard errors clustered at the municipality level. Data sources: Broadband Atlas Germany, BHP 7510

dummy generates two subsets that differ significantly in their base-year levels and growth rates of employment. Therefore, it cannot be credibly held that the OPAL dummy would be a valid IV in the model to be estimated, and hence it is not used in this study.

\section{Estimation results and discussion}

\subsection{Main results}

The main regression results are presented separately for manufacturing and service establishments, since previous literature points to heterogeneous effects between both sectors. Table 3 reports OLS estimates for Western Germany. Please recall that the results for Western Germany are based on a rural subsample of municipalities (those without an own MDF, and for which thus the IV approach can be applied). For manufacturers, the estimated employment growth coefficient of DSL availability is negative and not too far from statistical significance, unless year, industry, and district fixed effects are controlled for (with year fixed effects making the greatest 
Table 4 IV estimates, Western Germany

\begin{tabular}{|c|c|c|c|c|}
\hline Log employment growth rate & Manufacturing & & Services & \\
\hline \multicolumn{5}{|l|}{ Second stage } \\
\hline DSL availability & $-0.125(-1.36)$ & $-0.237(-2.30)^{* *}$ & $0.284(2.36)^{* *}$ & $0.325(3.14)^{* * *}$ \\
\hline Log full-time employment, est. & $0.004(1.65)^{*}$ & $-0.005(-1.79)^{*}$ & $0.002(0.62)$ & $\begin{array}{l}-0.000 \\
(-0.05)\end{array}$ \\
\hline Log median full-time wage, est. & $0.010(0.74)$ & $0.053(4.63)^{* * *}$ & $0.011(1.25)$ & $0.015(2.44)^{* *}$ \\
\hline Young establishment (<5 years) & $0.002(0.25)$ & $-0.007(-0.72)$ & $0.041(4.02)^{* * *}$ & $0.019(1.52)$ \\
\hline Mid-age establishment (5-14 years) & $0.002(0.20)$ & $-0.005(-0.75)$ & $0.016(2.13)^{* *}$ & $0.006(1.06)$ \\
\hline Share high-skilled & $0.067(2.14)^{* *}$ & $0.071(2.59)^{* * *}$ & $0.011(0.72)$ & $0.015(1.16)$ \\
\hline Log full-time employment, mun. & $0.004(0.99)$ & $0.003(0.76)$ & $-0.005(-0.93)$ & $-0.010(-1.94)^{*}$ \\
\hline Log full-time empl. density, mun. & $-0.007(-1.53)$ & $-0.004(-0.75)$ & $-0.022(-3.29)^{* * *}$ & $-0.010(-2.01)^{* *}$ \\
\hline Log mean full-time wage, mun. & $0.009(0.35)$ & $-0.001(-0.05)$ & $0.116(2.07)^{* *}$ & $0.123(2.97)^{* * *}$ \\
\hline Log full-time empl. growth rate, mun. & $0.039(1.38)$ & $-0.016(-0.67)$ & $0.024(0.36)$ & $0.013(0.18)$ \\
\hline Share high-skilled, municipality & $-0.047(-1.02)$ & $0.028(0.69)$ & $-0.092(-1.32)$ & $-0.048(-1.25)$ \\
\hline Year FE & & Yes & & Yes \\
\hline Industry FE (3-digit) & & Yes & & Yes \\
\hline District FE & & Yes & & Yes \\
\hline Observations & 14,823 & 14,823 & 18,650 & 18,650 \\
\hline Adjusted $R^{2}$ & 0.002 & 0.044 & ${ }^{a}$ & 0.034 \\
\hline \multicolumn{5}{|l|}{ First stage } \\
\hline Distance to MDF > $4.2 \mathrm{~km}$ & $-0.064(-4.38)^{* * *}$ & $-0.053(-7.35)^{* * *}$ & $-0.061(-3.86)^{* * *}$ & $-0.062(-5.34)^{* * *}$ \\
\hline Adjusted $R^{2}$ & 0.115 & 0.456 & 0.122 & 0.404 \\
\hline Robust F stat. & 19.221 & 54.294 & 14.930 & 28.646 \\
\hline Prob $>F$ & 0.000 & 0.000 & 0.000 & 0.000 \\
\hline Test of endogeneity $p$-value ${ }^{b}$ & 0.254 & 0.012 & 0.011 & 0.002 \\
\hline
\end{tabular}

a Not reported because model sum of squares is negative

b Wooldridge (1995) robust score test of regressor endogeneity ( $\mathrm{H} 0=$ exogenous). Data sources: Broadband Atlas Germany, Deutsche Telekom, BHP 7510

t statistics in parentheses. ${ }^{*} p<0.10,{ }^{* *} p<0.05,{ }^{* * *} p<0.01$. All estimations weighted by full-time employment. Constant omitted from output. Standard errors clustered at the municipality level

difference, probably due to the economic crisis of 20082009). In contrast, the inclusion of the control variables does not affect the DSL coefficient substantially. For the Western German service sector, the DSL coefficient from the more comprehensive specification, though insignificant at standard levels, indicates a positive relationship with employment growth.

Given that DSL availability is potentially endogenous, the OLS estimates may be biased due to reverse causality. However, since the OLS coefficients are not significantly different from zero, another bias might also be at work (and dominating the reverse causality bias), namely attenuation bias due to measurement error in the explanatory variable. As already discussed in Sect. 3.3, measurement error is quite plausible in this setting because DSL availability is measured at the municipality level while outcomes are measured at the establishment level. Therefore, in the following the IV estimates for Western German establishments are considered. These estimates suggest a significantly negative employment growth effect of DSL for manufacturers, and a positive effect for services (see
Table 4). The first-stage estimates indicate that the instrument is strong: The coefficients on the distance-threshold dummy (instrument) are around 0.06 and highly statistically significant, meaning that being above the threshold reduces the average sample municipality's DSL availability by about six percentage points. Furthermore, the $\mathrm{F}$ statistics are always above the threshold value of ten proposed by Stock et al. (2002). The estimate from the more comprehensive specification implies that, for the average services establishment, a 10 percentage point increase in DSL availability (a strong but realistic change from one year to the next) increases the employment growth rate by 3.25 percentage points, or 0.12 standard deviations. ${ }^{4}$ For illustration, this implies that an establishment growing from 30 to 31 employees with given DSL availability would instead grow to have 32 employees if DSL availability was ten percentage points higher.

\footnotetext{
${ }^{4}$ The sample-average employment growth rate is -0.4 percent for services $(-1.2$ percent for manufacturing) and its standard deviation is $0.263(0.262)$.
} 
Table 5 OLS estimates, Eastern Germany

\begin{tabular}{|c|c|c|c|c|}
\hline Log empl. growth rate & Manufacturing & & Services & \\
\hline DSL availability & $-0.007(-0.572)$ & $0.014(1.228)$ & $-0.008(-0.831)$ & $0.008(0.916)$ \\
\hline Log full-time employment, est. & $0.005(2.68)^{* * *}$ & $-0.000(-0.08)$ & $-0.001(-0.78)$ & $-0.001(-0.43)$ \\
\hline Log median full-time wage, est. & $-0.003(-0.41)$ & $0.012(1.30)$ & $0.010(1.93)^{*}$ & $0.011(1.84)^{*}$ \\
\hline Young establishment (<5 y.) & $0.009(0.84)$ & $-0.007(-0.70)$ & $-0.011(-1.33)$ & $-0.019(-1.98)^{* *}$ \\
\hline Mid-age establishment (5-14 y.) & $0.002(0.29)$ & $-0.011(-2.17)^{* *}$ & $-0.003(-0.62)$ & $-0.011(-1.94)^{*}$ \\
\hline Share high-skilled & $0.034(3.61)^{* * *}$ & $0.028(1.88)^{*}$ & $-0.004(-0.42)$ & $-0.006(-0.41)$ \\
\hline Log full-time employment, mun. & $-0.002(-1.00)$ & $-0.000(-0.08)$ & $-0.002(-0.78)$ & $-0.001(-0.38)$ \\
\hline Log full-time empl. density, mun. & $0.002(0.54)$ & $-0.001(-0.34)$ & $-0.001(-0.39)$ & $-0.002(-0.55)$ \\
\hline Log mean full-time wage, mun. & $0.024(1.08)$ & $0.005(0.22)$ & $0.040(1.58)$ & $0.023(1.09)$ \\
\hline Log full-time empl. growth rate, mun. & $0.052(1.71)^{*}$ & $0.055(1.73)^{*}$ & $0.004(0.15)$ & $0.041(1.28)$ \\
\hline Share high-skilled, municipality & $-0.012(-0.26)$ & $0.004(0.11)$ & $0.031(0.72)$ & $0.005(0.14)$ \\
\hline Year FE & & Yes & & Yes \\
\hline Industry FE (3-digit) & & Yes & & Yes \\
\hline District FE & & Yes & & Yes \\
\hline Observations & 26,472 & 26,472 & 51,882 & 51,882 \\
\hline Adjusted $R^{2}$ & 0.005 & 0.031 & 0.001 & 0.022 \\
\hline
\end{tabular}

t statistics in parentheses. ${ }^{*} p<0.10,{ }^{* *} p<0.05,{ }^{* * *} p<0.01$. All estimations weighted by full-time employment. Constant omitted from output. Standard errors clustered at the municipality level. Data sources: Broadband Atlas Germany, BHP 7510

OLS results for Eastern German establishments are presented in Table 5. There is no indication of a significant effect of DSL on employment growth, potentially due to measurement error in the DSL variable. Moreover, model fit is relatively poor for the Eastern sample. A possible reason for this pattern is the more urban geographic structure of the Eastern sample, meaning that this sample contains a greater diversity of establishments and hence, a larger variation of employment growth, some of which may be explained by unobserved factors.

The findings obtained so far raise the question why broadband apparently spurs job creation in services but appears to have the opposite effect for manufacturing. One answer might be that service firms are more intense users of broadband (Arntz et al. 2016), and that their internet use is complementary to employment. Akerman et al. (2015) investigate this channel of effects, failing to falsify it against a number of likely alternatives (such as demand-side product-market effects). Following this logic, the positive employment growth effect of DSL in the service sector might be driven by firms for which information is a key input and ICTs, such as broadband, are key technologies.

To assess this explanation, the above regressions are rerun for two subsets of industries: first, knowledge-intensive industries as defined by Eurostat $(2016)^{5}$; and second, computer-intensive industries, i.e. the top 50 percent of

\footnotetext{
${ }^{5}$ See Annex 7 “Knowledge Intensive Activities by NACE Rev.1.1”.
}

industries in terms of a computer use index defined by Falck et al. (2016). This index is based on the PIAAC survey of adult competencies conducted by the OECD, and it reflects the intensity of computer use by workers in the respective industry. ${ }^{6}$ Pooling Eastern and Western Germany, 20 percent of the sample establishments are classified as knowledge-intensive. Thereof, 90 percent belong to the service sector. Regarding computer intensity, 62 percent of the establishments with above-median computer use intensity belong to the service sector.

These results are displayed in Table 6 (OLS) and Table 7 (IV, Western Germany only). The estimates suggest positive employment growth effects for knowledge-intensive industries in both regional subsamples, as well as for computer-intensive industries in (rural) Western Germany. Although this is a plausible pattern of results, it does not necessarily imply that knowledge- or computerintensive industries are driving the positive effect found for Western German services, as the respective coefficients are not significantly different. For Eastern Germany, reassuringly, a significantly positive coefficient is found at least for the relatively small group of knowledgeintensive industries.

\footnotetext{
${ }^{6}$ PIAAC stands for Programme for the International Assessment of Adult Competencies. The computer use index indicates the frequency with which employees conduct the following tasks at work: Creating or reading spreadsheets; using word-processing software; using programming language; engaging in computer-aided real-time discussions.
} 
Table 6 OLS estimates, knowledge- and computer-intensive industries

\begin{tabular}{|c|c|c|c|c|}
\hline \multirow[t]{2}{*}{ Log employment growth rate } & \multicolumn{2}{|l|}{ Western Germany } & \multicolumn{2}{|l|}{ Eastern Germany } \\
\hline & $\begin{array}{l}\text { Knowledge-intensive } \\
\text { industries }\end{array}$ & $\begin{array}{l}\text { Computer-intensive } \\
\text { industries }\end{array}$ & $\begin{array}{l}\text { Knowledge-intensive } \\
\text { industries }\end{array}$ & $\begin{array}{l}\text { Computer- } \\
\text { intensive } \\
\text { industries }\end{array}$ \\
\hline DSL availability & $0.199(1.55)$ & $0.086(2.28)^{* *}$ & $0.064(2.30)^{* *}$ & $0.002(0.19)$ \\
\hline Establishment controls & Yes & Yes & Yes & Yes \\
\hline Municipality controls & Yes & Yes & Yes & Yes \\
\hline Year FE & Yes & Yes & Yes & Yes \\
\hline Industry FE (3-digit) & Yes & Yes & Yes & Yes \\
\hline District FE & Yes & Yes & Yes & Yes \\
\hline Observations & 5868 & 17,740 & 16,608 & 41,251 \\
\hline Adjusted $R^{2}$ & 0.150 & 0.053 & 0.048 & 0.018 \\
\hline
\end{tabular}

$\mathrm{t}$ statistics in parentheses. ${ }^{*} \mathrm{p}<0.10,{ }^{* *} \mathrm{p}<0.05,{ }^{* * *} \mathrm{p}<0.01$. All estimations weighted by full-time employment. Constant omitted from output. Standard errors clustered at the municipality level. Data sources: Broadband Atlas Germany, BHP 7510

Table 7 IV estimates, Western Germany, knowledge- and computer-intensive industries

\begin{tabular}{|c|c|c|c|c|}
\hline \multirow{2}{*}{$\begin{array}{l}\text { Log empl. growth rate } \\
\text { Second stage }\end{array}$} & \multicolumn{2}{|c|}{ Knowledge-intensive industries } & \multicolumn{2}{|c|}{ Computer-intensive industries } \\
\hline & & & & \\
\hline DSL availability & $0.454(1.95)^{*}$ & $0.616(3.12)^{* * *}$ & $0.269(2.24)^{* *}$ & $0.273(3.38)^{* * *}$ \\
\hline Establishment controls & Yes & Yes & Yes & Yes \\
\hline Municipality controls & Yes & Yes & Yes & Yes \\
\hline Year FE & & Yes & & Yes \\
\hline Industry FE (3-digit) & & Yes & & Yes \\
\hline District FE & & Yes & & Yes \\
\hline Observations & 5868 & 5868 & 17,740 & 17,740 \\
\hline Adjusted $R^{2}$ & 0.022 & 0.135 &.$^{a}$ & 0.045 \\
\hline \multicolumn{5}{|l|}{ First stage } \\
\hline Distance to MDF > $4.2 \mathrm{~km}$ & $-0.067(-2.65)^{* * *}$ & $-0.054(-4.96)^{* * *}$ & $-0.054(-4.74)^{* * *}$ & $-0.059(-6.53)^{* * *}$ \\
\hline Adjusted $R^{2}$ & 0.263 & 0.620 & 0.134 & 0.402 \\
\hline Robust F stat. & 7.030 & 25.246 & 22.462 & 42.929 \\
\hline Prob $>F$ & 0.008 & 0.000 & 0.000 & 0.000 \\
\hline Test of endogeneity $p$-value ${ }^{\ddagger}$ & 0.174 & 0.038 & 0.012 & 0.013 \\
\hline
\end{tabular}

${ }^{a}$ Not reported because model sum of squares is negative. All estimations weighted by full-time employment. Constant omitted from output. Standard errors clustered at the municipality level

₹ Wooldridge (1995) robust score test of regressor endogeneity ( $\mathrm{H0}=$ exogenous). Data sources: Broadband Atlas Germany, Deutsche Telekom, BHP 7510 t statistics in parentheses. ${ }^{*} \mathrm{p}<0.10,{ }^{* *} \mathrm{p}<0.05,{ }^{* * *} \mathrm{p}<0.01$

\subsection{Robustness checks}

To assess the robustness of the IV results, it is first tested whether the estimates are sensitive to the measurement problem inherent to the distance-based IV approach. Defining the IV, every municipality was assigned a value of zero or one, depending on the distance between its centroid and the MDF. Regarding individual establishments, this distance is necessarily measured with error. To tackle this problem, two alternative approaches are taken to quantify the degree to which a municipality is subject to technical obstacles.
First, following Falck et al. (2014), the same distance is measured from the municipality's population-weighted centroid, rather than its geographic centroid. ${ }^{7}$ Thereby, the value of the IV changes for 13 percent of the Western German municipalities, mostly from one (above the threshold) to zero (below the threshold), which is plausible because MDFs are placed in or near buildings and therefore

\footnotetext{
${ }^{7}$ For details on the identification of population-weighted centroids, see Falck et al. (2014), who use the same data on DSL availability and MDF locations. The data sources used are Google Earth and the Corine Land Cover database.
} 


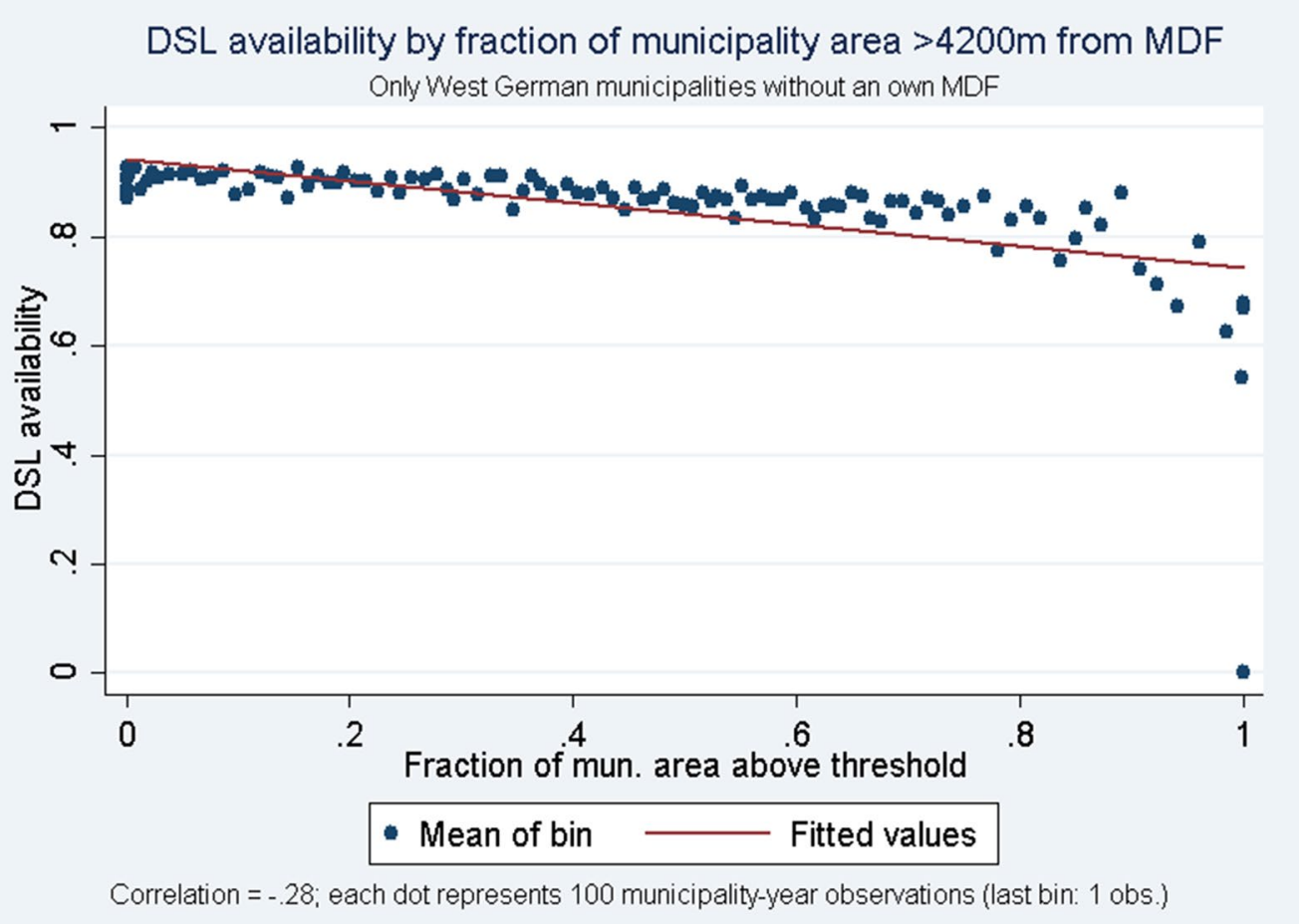

Fig. 3 Relevance of the alternative IV (land area share above the threshold). Data sources: Broadband Atlas Germany, Deutsche Telekom, Google Earth, Corine Land Cover database

necessarily closer to the population-weighted than the geographic centroid. For the same reason, when using the population-weighted centroid, slightly more municipalities are found to be less than $4.2 \mathrm{~km}$ distant from their nearest (not originally assigned) MDF. As before, these municipalities are dropped, which results in a slightly smaller sample compared to the previous estimations. Second, the threshold-dummy IV is replaced by the share of the municipality's land area that is more than $4.2 \mathrm{~km}$ distant from the assigned MDF. The relationship between this variable and DSL availability is illustrated in Fig. 3, which shows a significant negative relationship between this alternative, continuous IV and DSL availability.

The estimates from both robustness exercises are close to those obtained with the main IV, see Table 8, although the results for manufacturing turn out to be less robust than those for services. Therefore, at least for the services subsample, the estimates based on the binary distancethreshold IV are not driven by the peculiar measurement of distance between 'the municipality' and the MDF.

In another robustness check, similar to Falck et al. (2014), as an alternative to instrumenting DSL availability, a long-difference model is estimated (technically a first-difference model) which identifies the effect of DSL based on the change in DSL availability between the
pre-DSL period (up to 1999) and the main observation period, when DSL was available. This model can be formulated as

$$
\begin{aligned}
\Delta \ln \left(\frac{L_{i t+1}}{L_{i t}}\right)= & \ln \left(\frac{L_{i t+1}}{L_{i t}}\right)-\ln \left(\frac{L_{i, 1999}}{L_{i, 1998}}\right) \\
= & \beta_{0}^{\prime}+\beta_{1}^{\prime} \Delta D S L_{m t}+\boldsymbol{\beta}^{\prime}{ }_{2} \Delta \boldsymbol{X}_{\boldsymbol{i t}} \\
& +\boldsymbol{\beta}^{\prime}{ }_{3} \Delta \boldsymbol{X}^{\prime}{ }_{\boldsymbol{m} \boldsymbol{t}}+\mu_{t}^{\prime}+\varepsilon_{i t}^{\prime} .
\end{aligned}
$$

In constructing the differences of employment growth (second term of Eq. 3), there are several alternative values for $t(2006,2007,2008)$, that is, the year-to-year employment growth rates for 2006-2007, 2007-2008, and 2008-2009. On the right-hand-side of the equation, the differences are constructed between the various years $t$ and the base year 1999. Note that $\triangle D S L_{m t}$ is identical to $D S L_{m t}$ (as in Eqs. 1 and 2), since DSL was not available before 2000. Due to first-differencing, the estimation samples are reduced to about 70 percent of their original size for manufacturing, and about 60 percent for services.

Regarding Western Germany (Table 9), at least for $t=(2006,2007)$, these estimations confirm the positive employment growth effect of DSL availability in the service sector, whereas the negative employment growth effect for manufacturing establishments found in the main 
Table 8 IV estimates, alternative IVs (Western Germany)

\begin{tabular}{|c|c|c|c|c|}
\hline Log employment growth rate & Manufacturing & & Services & \\
\hline \multicolumn{5}{|l|}{ Second stage } \\
\hline DSL availability & $-0.143(-1.50)$ & $-0.053(-0.74)$ & $0.194^{* *}(2.18)$ & $0.225^{* * *}(2.87)$ \\
\hline Establishment controls & Yes & Yes & Yes & Yes \\
\hline Municipality controls & Yes & Yes & Yes & Yes \\
\hline Year FE & Yes & Yes & Yes & Yes \\
\hline Industry FE (3-digit) & Yes & Yes & Yes & Yes \\
\hline District FE & Yes & Yes & Yes & Yes \\
\hline Observations & 14,029 & 14,823 & 17,706 & 18,650 \\
\hline Adjusted $R^{2}$ & 0.060 & 0.064 & 0.052 & 0.047 \\
\hline \multicolumn{5}{|l|}{ First stage } \\
\hline $\begin{array}{l}\text { Distance to MDF }>4.2 \mathrm{~km} \text { (measured from population- } \\
\text { weighted centroid) }\end{array}$ & $-0.063(-6.50)^{* * *}$ & & $-0.084(-5.52)^{* * *}$ & \\
\hline Share of land area above $4.2 \mathrm{~km}$ distance threshold & & $-0.110(-5.80)^{* * *}$ & & $-0.157(-5.94)^{* * *}$ \\
\hline Adj. R-sq. & 0.463 & 0.461 & 0.410 & 0.427 \\
\hline Robust F stat. & 42.424 & 33.837 & 30.665 & 35.465 \\
\hline Prob $>F$ & 0.000 & 0.000 & 0.000 & 0.000 \\
\hline Test of endogeneity $p$-value ${ }^{a}$ & 0.117 & 0.444 & 0.074 & 0.010 \\
\hline
\end{tabular}

a Wooldridge (1995) robust score test of regressor endogeneity (H0=exogenous). Data sources: Broadband Atlas Germany, Deutsche Telekom, Google Earth, Corine Land Cover database, BHP 7510

t statistics in parentheses. ${ }^{*} p<0.10,{ }^{* *} p<0.05,{ }^{* * *} p<0.01$. All estimations weighted by full-time employment. Constant omitted from output. Standard errors clustered at the municipality level

Table 9 Long difference estimates, Western Germany

\begin{tabular}{|c|c|c|c|c|c|c|}
\hline \multirow{2}{*}{ Dep. var.: $\Delta \ln \left(\frac{L_{i t+1}}{L_{i t}}\right)$} & \multicolumn{2}{|l|}{$t=2006$} & \multicolumn{2}{|l|}{$t=2007$} & \multicolumn{2}{|l|}{$t=2008$} \\
\hline & Manuf. & Services & Manuf. & Services & Manuf. & Services \\
\hline$\triangle D S L$ availability & $0.093(1.46)$ & $0.194(2.44)^{* *}$ & $0.091(1.00)$ & $0.195(2.52)^{* *}$ & $0.072(0.59)$ & $0.031(0.42)$ \\
\hline Establishment controls & Yes & Yes & Yes & Yes & Yes & Yes \\
\hline Municipality controls & Yes & Yes & Yes & Yes & Yes & Yes \\
\hline Observations & 2215 & 2376 & 2120 & 2278 & 2032 & 2198 \\
\hline Adjusted $R^{2}$ & 0.106 & 0.060 & 0.078 & 0.086 & 0.094 & 0.107 \\
\hline
\end{tabular}

t statistics in parentheses. ${ }^{*} \mathrm{p}<0.10,{ }^{* *} \mathrm{p}<0.05,{ }^{* * *} \mathrm{p}<0.01$. All estimations weighted by full-time employment. Constant omitted from output. Standard errors clustered at the municipality level. Data sources: Broadband Atlas Germany, Deutsche Telekom, BHP 7510

specification once more is not confirmed. For $t=2008$, no significant employment growth effects are found using the long-difference model. This could be due to the 2008/2009 recession (due to first-differencing, year fixed effects cannot be used in this specification). For Eastern Germany (Table 10), partly positive employment growth effects are found for both sectors. However, the pattern of estimates for Eastern Germany seems less plausible and robust across different values of $t$. Regarding quantitative interpretation, the estimates for $t=2007$ and service establishments imply that a ten percentage point increase of DSL availability (from zero) between 1999 and 2007 is related to an increase of employment growth by 1.95 percentage points (West), respectively 0.86 percentage points (East).
In further robustness checks, the five percent largest establishments within both sectoral subsamples are dropped, as well as establishments with 250 or more employees. The largest establishments have considerable weight due to the employment-weighting of the regressions. The results, displayed in Table 14 in "Appendix", largely confirm the results of the main estimations. Again, only the positive employment growth effect of DSL availability in the service sector proves robustly significant. A similar pattern is found if the weights are not used (Table 15 in the "Appendix").

In some final robustness checks (results not reported), rather than total employment, full-time and full-timeequivalent employment are used to construct the 
Table 10 Long difference estimates, Eastern Germany

\begin{tabular}{|c|c|c|c|c|c|c|}
\hline \multirow{2}{*}{ Dep. var.: $\Delta \ln \left(\frac{L_{i t+1}}{L_{i t}}\right)$} & \multicolumn{2}{|l|}{$t=2006$} & \multicolumn{2}{|l|}{$t=2007$} & \multicolumn{2}{|l|}{$t=2008$} \\
\hline & Manuf. & Services & Manuf. & Services & Manuf. & Services \\
\hline$\triangle \mathrm{DSL}$ availability & $0.031(0.62)$ & $0.021(0.39)$ & $0.103(2.14)^{* *}$ & $0.086(1.93)^{*}$ & $0.046(0.69)$ & $0.171(2.33)^{* *}$ \\
\hline Establishment controls & Yes & Yes & Yes & Yes & Yes & Yes \\
\hline Municipality controls & Yes & Yes & Yes & Yes & Yes & Yes \\
\hline Observations & 3732 & 6443 & 3588 & 6148 & 3424 & 5777 \\
\hline Adjusted $R^{2}$ & 0.093 & 0.054 & 0.118 & 0.103 & 0.116 & 0.202 \\
\hline
\end{tabular}

$\mathrm{t}$ statistics in parentheses. ${ }^{*} \mathrm{p}<0.10,{ }^{* *} \mathrm{p}<0.05,{ }^{* * *} \mathrm{p}<0.01$. All estimations weighted by full-time employment. Constant omitted from output. Standard errors clustered at the municipality level. Data sources: Broadband Atlas Germany, Deutsche Telekom, BHP 7510

employment growth rate. Furthermore, the years 2008 and 2008-2009 are excluded to check if the estimates are biased by macroeconomic shocks related to the $2008 / 2009$ financial crisis. The results do not change substantially in response to any of these alterations.

\section{Conclusions}

This article investigates the effect of broadband internet availability on the employment growth of German business establishments in the period 2005-2010. The analysis is carried out for different subsamples, separating rural Western Germany and Eastern Germany as well as manufacturing and service establishments. To obtain causal estimates, technical frictions which impeded the rollout of broadband in rural Western Germany are used to construct an instrumental variable for local broadband availability, largely following Falck et al. (2014).

In line with previous empirical literature, the empirical results for Western Germany suggest that broadband expansion has helped service establishments create jobs. The magnitude of this employment growth effect is substantial: A ten percentage point increase in DSL availability is associated with an increase in the employment growth rate of two to three percentage points. Also in line with previous research, a significantly positive effect is found for knowledge-intensive industries. In contrast, for Western German manufacturers a negative employment growth effect of similar magnitude is found, which however turns out to be less robust to changes of the estimated specification. The internal validity of the findings is supported by robustness checks concerning in particular the definition of the instrument.

For Eastern Germany, although a feasible IV approach is available, it turns out invalid in this setting. However, a long difference regression provides some evidence of a positive effect (for both sectors but primarily for services) of similar absolute magnitude as in Western Germany. Furthermore, there is some evidence (from OLS estimations) of a positive effect for Eastern German knowledge-intensive industries.
The finding of a service-biased job creation effect, or even a reallocation of job creation from manufacturing to services, is in line with theoretical considerations and previous empirical literature, which finds the same sectoral pattern. Due to the focus on employment growth at the establishment level and broadband availability at the establishment location, the findings of this study suggest that broadband affects employment growth through its productive use in firms, with service firms being more apt to use it than manufacturers. Moreover, broadband may induce outsourcing of manufacturing jobs to the service sector, which would be in line with the opposite signs estimated for both sectors, but cannot be identified with the data at hand. Furthermore, a fast broadband connection may enable employees to work from home and enable more flexible work hours. Thereby, broadband can help reconcile work and family duties and thus increase labor supply, notably for high-qualified women with children (Dettling 2017). These channels of effects, which would merit further empirical investigation given the necessary data, are also in line with the service-biased employment growth effect of broadband internet found in this study.

\section{Acknowledgements}

I thank Oliver Falck, Andreas Mazat, and Tobias Lohse for sharing their data and expertise on broadband availability. Thanks also to Uwe Blien, Daniel F. Heuermann, Johannes Ludsteck, Thomas Zwick, two anonymous referees, and the editor at the Journal for Labour Market Research for helpful comments, and to Klara Kaufmann for excellent research assistance. Comments from conference and seminar participants at the Ifo Institute (Center for Industrial Organisation and New Technologies Seminar, 2016, Munich), the SERC Conference (2016, London), the ERSA Congress (2016, Vienna), the ZEW/IAB/BiBB Workshop (2016, Mannheim), the EALE Annual Conference (2017, St. Gallen) and the University of Würzburg (2017) are highly acknowledged. The author acknowledges financial support from the joint graduate program of IAB and Friedrich-Alexander University of Erlangen-Nuremberg (GradAB).

\section{Authors' contributions}

The author read and approved the final manuscript.

Funding

This study was conducted while the author was an employee of IAB and scholarship holder in IAB's graduate program (GradAB). However, the author did not receive any specific funding for this particular study. 
Availability of data and materials

The datasets generated and analysed during the current study are not publicly available due to data protection laws (social security data) but can be accessed on-site at the Institute for Employment Research (IAB) subject to an individual data protection agreement.

Competing interests

The author declares that he has no competing interests.

\section{Appendix}

\section{Sample restrictions}

The samples of establishments I use are based on a ten percent random sample from all establishments observed in the BHP between 2005 and 2009. I restrict this sample as follows: First, I exclude establishments which appear in the BHP for the first time in 2005 or later, since these may have been attracted to their particular location exactly because of broadband availability. To do so, I use the BHP's information on the first appearance of each establishment ID. These are the establishment ID entry variable created by Hethey and Schmieder (2010) and the first appearance date of the ID.

Furthermore, I limit the sample to establishment observations with at least one full-time employee, since only for these, the establishment's median gross daily wage, used as a control variable, is observed (the IAB data do not contain precise working hours or hourly wages). I also check for implausible values and outliers in important establishment characteristics, dropping some rare establishment observations with a reported median daily wage for full-time workers below 10 Euros (this concerns less than one percent of establishment observations). Such implausibly low values can arise if a substantial fraction of an establishment's workers (typically in very small establishments) hold a position but are not actively working, as is the case during sickness leave (after six weeks), maternity leave, or sabbaticals. Finally, I drop all observations below the first and above the $99^{\text {th }}$ percentile in terms of employment growth, as there are a small number of establishment observations with implausibly small (negative) or large growth rates.

At the municipality level, I drop all observations of Berlin because the DSL data do not report separate values of DSL availability for the formerly separate Eastern and Western parts of the city, although these have historically different telecommunication infrastructures.

See Tables 11, 12, 13, 14 and 15; Figs. 4, 5 and 6. 
Table 11 Summary statistics, Western sample

\begin{tabular}{|c|c|c|c|c|c|}
\hline Establishment level & Count & Mean & SD & Min & Max \\
\hline \multicolumn{6}{|l|}{ Manufacturing } \\
\hline Log empl. growth rate & 14,823 & -0.012 & 0.262 & -1.099 & 0.811 \\
\hline Full-time employment & 14,823 & 13.580 & 49.362 & 1.000 & 1377.000 \\
\hline Log full-time empl. (estab.) & 14,823 & 1.480 & 1.247 & 0.000 & 7.228 \\
\hline Log median wage (estab.) & 14,823 & 4.239 & 0.399 & 2.319 & 5.208 \\
\hline Young estab. & 14,823 & 0.060 & 0.238 & 0.000 & 1.000 \\
\hline Mid-age estab. & 14,823 & 0.344 & 0.475 & 0.000 & 1.000 \\
\hline Share high-skilled (occ.) & 14,823 & 0.054 & 0.145 & 0.000 & 1.000 \\
\hline \multicolumn{6}{|l|}{ Services } \\
\hline Log empl. growth rate & 18,650 & -0.004 & 0.263 & -1.099 & 0.827 \\
\hline Full-time employment & 18,650 & 6.867 & 21.668 & 1.000 & 732.000 \\
\hline Log full-time empl. (estab.) & 18,650 & 1.062 & 1.086 & 0.000 & 6.596 \\
\hline Log median wage (estab.) & 18,650 & 4.093 & 0.558 & 2.306 & 5.246 \\
\hline Young estab. & 18,650 & 0.095 & 0.293 & 0.000 & 1.000 \\
\hline Mid-age estab. & 18,650 & 0.404 & 0.491 & 0.000 & 1.000 \\
\hline Share high-skilled (occ.) & 18,650 & 0.091 & 0.219 & 0.000 & 1.000 \\
\hline \multicolumn{6}{|l|}{ Municipality level } \\
\hline DSL availability & 10,901 & 0.865 & 0.166 & 0.000 & 1.000 \\
\hline Distance to assigned MDF > 4200 m (IV) & 10,901 & 0.374 & 0.484 & 0.000 & 1.000 \\
\hline $\begin{array}{l}\text { Distance to MDF > } 4200 \mathrm{~m} \text {, population-weighted centroid } \\
\text { (alternative IV) }\end{array}$ & 10,356 & 0.283 & 0.450 & 0.000 & 1.000 \\
\hline Fraction of land area $>4200 \mathrm{~m}$ from MDF (alt. IV) & 10,901 & 0.428 & 0.299 & 0.000 & 1.000 \\
\hline Log full-time empl., municip. & 10,901 & 5.140 & 1.248 & 0.693 & 10.113 \\
\hline Log full-time empl. density, municip. & 10,901 & 2.527 & 1.224 & -1.816 & 7.617 \\
\hline Log mean wage (full-time), municip. & 10,901 & 4.339 & 0.172 & 2.913 & 5.137 \\
\hline Log full-time empl. growth rate, municip. & 10,901 & 0.004 & 0.144 & -3.091 & 1.497 \\
\hline Share high-skilled (occ.), municip. & 10,901 & 0.118 & 0.077 & 0.000 & 0.649 \\
\hline Own MDF (yes/no) & 10,901 & 0.000 & 0.000 & 0.000 & 0.000 \\
\hline Distance to assigned MDF & 10,901 & 3875.177 & 1430.371 & 304.452 & $10,200.920$ \\
\hline Distance to assigned MDF, pop.-w. centroid & 10,901 & 3577.541 & 1557.988 & 25.692 & $10,093.380$ \\
\hline Distance to nearest MDF & 10,901 & 3744.732 & 1316.459 & 86.527 & 9988.840 \\
\hline Distance to nearest MDF, pop.-w. centroid & 10,901 & 3343.899 & 1362.057 & 25.692 & 9338.061 \\
\hline
\end{tabular}

Data sources: Broadband Atlas Germany, Deutsche Telekom, Google Earth, Corine Land Cover database, BHP 7510 
Table 12 Summary statistics, Eastern sample

\begin{tabular}{|c|c|c|c|c|c|}
\hline Establishment level & Count & Mean & SD & Min & Max \\
\hline \multicolumn{6}{|l|}{ Manufacturing } \\
\hline Log empl. growth rate & 26,472 & -0.016 & 0.276 & -1.099 & 0.833 \\
\hline Full-time employment & 26,472 & 15.875 & 60.038 & 1.000 & 3172.000 \\
\hline Log full-time empl. (estab.) & 26,472 & 1.644 & 1.279 & 0.000 & 8.062 \\
\hline Log median wage (estab.) & 26,472 & 3.974 & 0.353 & 2.306 & 5.208 \\
\hline Young estab. & 26,472 & 0.092 & 0.289 & 0.000 & 1.000 \\
\hline Mid-age estab. & 26,472 & 0.563 & 0.496 & 0.000 & 1.000 \\
\hline Share high-skilled (occ.) & 26,472 & 0.084 & 0.192 & 0.000 & 1.000 \\
\hline \multicolumn{6}{|l|}{ Services } \\
\hline Log empl. growth rate & 51,882 & -0.014 & 0.272 & -1.099 & 0.827 \\
\hline Full-time employment & 51,882 & 8.155 & 25.488 & 1.000 & 1004.000 \\
\hline Log full-time empl. (estab.) & 51,882 & 1.173 & 1.138 & 0.000 & 6.912 \\
\hline Log median wage (estab.) & 51,882 & 3.873 & 0.512 & 2.306 & 5.198 \\
\hline Young estab. & 51,882 & 0.107 & 0.310 & 0.000 & 1.000 \\
\hline Mid-age estab. & 51,882 & 0.638 & 0.481 & 0.000 & 1.000 \\
\hline Share high-skilled (occ.) & 51,882 & 0.123 & 0.260 & 0.000 & 1.000 \\
\hline \multicolumn{6}{|l|}{ Municipality level } \\
\hline DSL availability & 9602 & 0.742 & 0.292 & 0.000 & 1.000 \\
\hline Log full-time empl., municip. & 9602 & 5.800 & 1.590 & 0.693 & 11.963 \\
\hline Log full-time empl. density, municip. & 9602 & 2.499 & 1.317 & -2.296 & 6.182 \\
\hline Log mean wage (full-time), municip. & 9602 & 4.071 & 0.154 & 3.142 & 4.861 \\
\hline Log full-time empl. growth rate, municip. & 9602 & -0.008 & 0.135 & -1.521 & 2.570 \\
\hline Share high-skilled (occ.), municip. & 9602 & 0.142 & 0.079 & 0.000 & 0.676 \\
\hline
\end{tabular}

Data sources: Broadband Atlas Germany, BHP 7510

Table 13 Sampled vs. not sampled municipalities, Western Germany

\begin{tabular}{|c|c|c|c|c|c|}
\hline Not sampled & Count & Mean & SD & Min & Max \\
\hline DSL availability & 17,694 & 0.895 & 0.123 & 0.000 & 1.000 \\
\hline Population (as of 2008) & 17,694 & $16,222.434$ & $55,747.383$ & 150.000 & $1774,223.875$ \\
\hline Land area (sq. km) & 17,694 & 50.278 & 42.263 & 1.750 & 755.160 \\
\hline Population density & 17,694 & 308.591 & 389.297 & 5.785 & 4282.211 \\
\hline Full-time empl., municipality & 17,694 & 4100.029 & $19,088.577$ & 2.000 & $579,094.000$ \\
\hline Full-time empl. density & 17,694 & 67.691 & 122.836 & 0.268 & 2002.103 \\
\hline Share high-qual. (FT), municip. & 17,694 & 0.052 & 0.045 & 0.000 & 0.614 \\
\hline Mean wage (FT), municipality & 17,694 & 82.387 & 13.089 & 23.696 & 166.817 \\
\hline \multicolumn{6}{|l|}{ Sampled } \\
\hline DSL availability & 10,901 & 0.865 & 0.166 & 0.000 & 1.000 \\
\hline Population (as of 2008) & 10,901 & 2532.747 & 2437.176 & 39.000 & $22,895.000$ \\
\hline Land area (sq. km) & 10,901 & 17.396 & 12.755 & 0.450 & 131.650 \\
\hline Population density & 10,901 & 191.980 & 202.272 & 4.061 & 2270.000 \\
\hline Full-time empl., municipality & 10,901 & 368.726 & 773.656 & 1.000 & $24,664.000$ \\
\hline Full-time empl. density & 10,901 & 27.714 & 61.381 & 0.163 & 2033.306 \\
\hline Share high-qual. (FT), municip. & 10,901 & 0.037 & 0.046 & 0.000 & 0.616 \\
\hline Mean wage (FT), municipality & 10,901 & 76.795 & 13.600 & 17.418 & 169.196 \\
\hline
\end{tabular}

Data sources: Broadband Atlas Germany, Deutsche Telekom, Google Earth, Corine Land Cover database, BHP 7510, Federal Statistical Office (Destatis) 
Table 14 Subsamples excluding the largest establishments

\begin{tabular}{|c|c|c|c|c|c|c|}
\hline \multirow[b]{2}{*}{ Log empl. growth rate } & \multicolumn{4}{|l|}{ Western Germany } & \multicolumn{2}{|c|}{ Eastern Germany } \\
\hline & \multicolumn{2}{|l|}{ OLS } & \multicolumn{2}{|l|}{ IV (second stage) } & \multicolumn{2}{|l|}{ OLS } \\
\hline \multicolumn{7}{|c|}{ Excluding the $5 \%$ largest establishments } \\
\hline \multicolumn{7}{|l|}{ Manufacturing } \\
\hline DSL availability & $-0.031(-1.77)^{*}$ & $0.022(1.20)$ & $-0.084(-0.82)$ & $-0.118(-1.05)$ & $0.009(0.89)$ & 0.009 (0.94) \\
\hline Establishment controls & Yes & Yes & Yes & Yes & Yes & Yes \\
\hline Municipality controls & Yes & Yes & Yes & Yes & Yes & Yes \\
\hline Year FE & & Yes & & Yes & & Yes \\
\hline Industry FE (3-digit) & & Yes & & Yes & & Yes \\
\hline District FE & & Yes & & Yes & & Yes \\
\hline Observations & 14,078 & 14,078 & 14,078 & 14,078 & 25,133 & 25,133 \\
\hline Adjusted $R^{2}$ & 0.005 & 0.030 & 0.004 & 0.025 & 0.001 & 0.015 \\
\hline \multicolumn{7}{|c|}{ Services (controls and FE as above) } \\
\hline DSL availability & $-0.025(-1.68)^{*}$ & $-0.017(-1.13)$ & $0.187(1.79)^{*}$ & $0.253(2.38)^{* *}$ & $-0.002(-0.24)$ & $-0.002(-0.23)$ \\
\hline Observations & 17,700 & 17,700 & 17,700 & 17,700 & 49,267 & 49,267 \\
\hline Adjusted $R^{2}$ & 0.002 & 0.009 & $\stackrel{a}{a}$ & -0.011 & 0.000 & 0.007 \\
\hline \multicolumn{7}{|c|}{ Excluding establishments > 249 employees (controls and FE as above) } \\
\hline \multicolumn{7}{|l|}{ Manufacturing } \\
\hline DSL availability & $-0.025(-1.33)$ & $0.015(0.81)$ & $-0.051(-0.61)$ & $-0.241(-2.31)^{* *}$ & $-0.012(-1.10)$ & $-0.005(-0.48)$ \\
\hline Observations & 14,716 & 14,716 & 14,716 & 14,716 & 26,283 & 26,283 \\
\hline Adjusted $R^{2}$ & 0.006 & 0.053 & 0.005 & 0.032 & 0.003 & 0.034 \\
\hline \multicolumn{7}{|l|}{ Services } \\
\hline DSL availability & $0.016(0.63)$ & $0.017(0.92)$ & $0.278(2.50)^{* *}$ & $0.274(2.79)^{* * *}$ & $-0.006(-0.85)$ & 0.008 (1.09) \\
\hline Observations & 18,620 & 18,620 & 18,620 & 18,620 & 51,797 & 51,797 \\
\hline Adjusted $R^{2}$ & 0.005 & 0.039 & $\stackrel{a}{a}$ & 0.017 & 0.000 & 0.015 \\
\hline
\end{tabular}

$\mathrm{t}$ statistics in parentheses. ${ }^{*} \mathrm{p}<0.10,{ }^{* *} \mathrm{p}<0.05,{ }^{* * *} \mathrm{p}<0.01$. All estimations weighted by full-time employment. Constant omitted from output. Standard errors clustered at the municipality level. ${ }^{a}$ Not reported because model sum of squares is negative. Data sources: Broadband Atlas Germany, Deutsche Telekom, BHP 7510

Table 15 Unweighted regressions

\begin{tabular}{|c|c|c|c|c|c|c|}
\hline \multirow[t]{2}{*}{ Log empl. growth rate } & \multicolumn{4}{|l|}{ Western Germany } & \multicolumn{2}{|l|}{ Eastern Germany } \\
\hline & \multicolumn{2}{|l|}{ OLS } & \multicolumn{2}{|l|}{ IV (second stage) } & \multicolumn{2}{|l|}{ OLS } \\
\hline \multicolumn{7}{|l|}{ Manufacturing } \\
\hline DSL availability & $-0.039(-2.48)^{* *}$ & $-0.016(-0.94)$ & $-0.022(-0.31)$ & $-0.051(-0.62)$ & $0.002(0.28)$ & $0.003(0.36)$ \\
\hline Establishment controls & Yes & Yes & Yes & Yes & Yes & Yes \\
\hline Municipality controls & Yes & Yes & Yes & Yes & Yes & Yes \\
\hline Year FE & & Yes & & Yes & & Yes \\
\hline Industry FE (3-digit) & & Yes & & Yes & & Yes \\
\hline District FE & & Yes & & Yes & & Yes \\
\hline Observations & 14,823 & 14,823 & 14,823 & 14,823 & 26,472 & 26,472 \\
\hline Adjusted $R^{2}$ & 0.003 & -0.000 & 0.003 & -0.001 & 0.001 & 0.002 \\
\hline \multicolumn{7}{|c|}{ Services (controls and FE as above) } \\
\hline DSL availability & $-0.008(-0.53)$ & $-0.007(-0.45)$ & $0.239(2.80)^{* * *}$ & $0.255(2.94)^{* * *}$ & $-0.004(-0.64)$ & $-0.005(-0.69)$ \\
\hline Observations & 18,650 & 18,650 & 18,650 & 18,650 & 51,882 & 51,882 \\
\hline Adjusted $R^{2}$ & 0.002 & 0.001 & a & -0.013 & 0.001 & 0.002 \\
\hline
\end{tabular}

a Not reported because model sum of squares is negative. Data sources: Broadband Atlas Germany, Deutsche Telekom, BHP 7510

t statistics in parentheses. ${ }^{*} p<0.10,{ }^{* *} p<0.05,{ }^{* * *} p<0.01$. Constant omitted from output. Standard errors clustered at the municipality level 


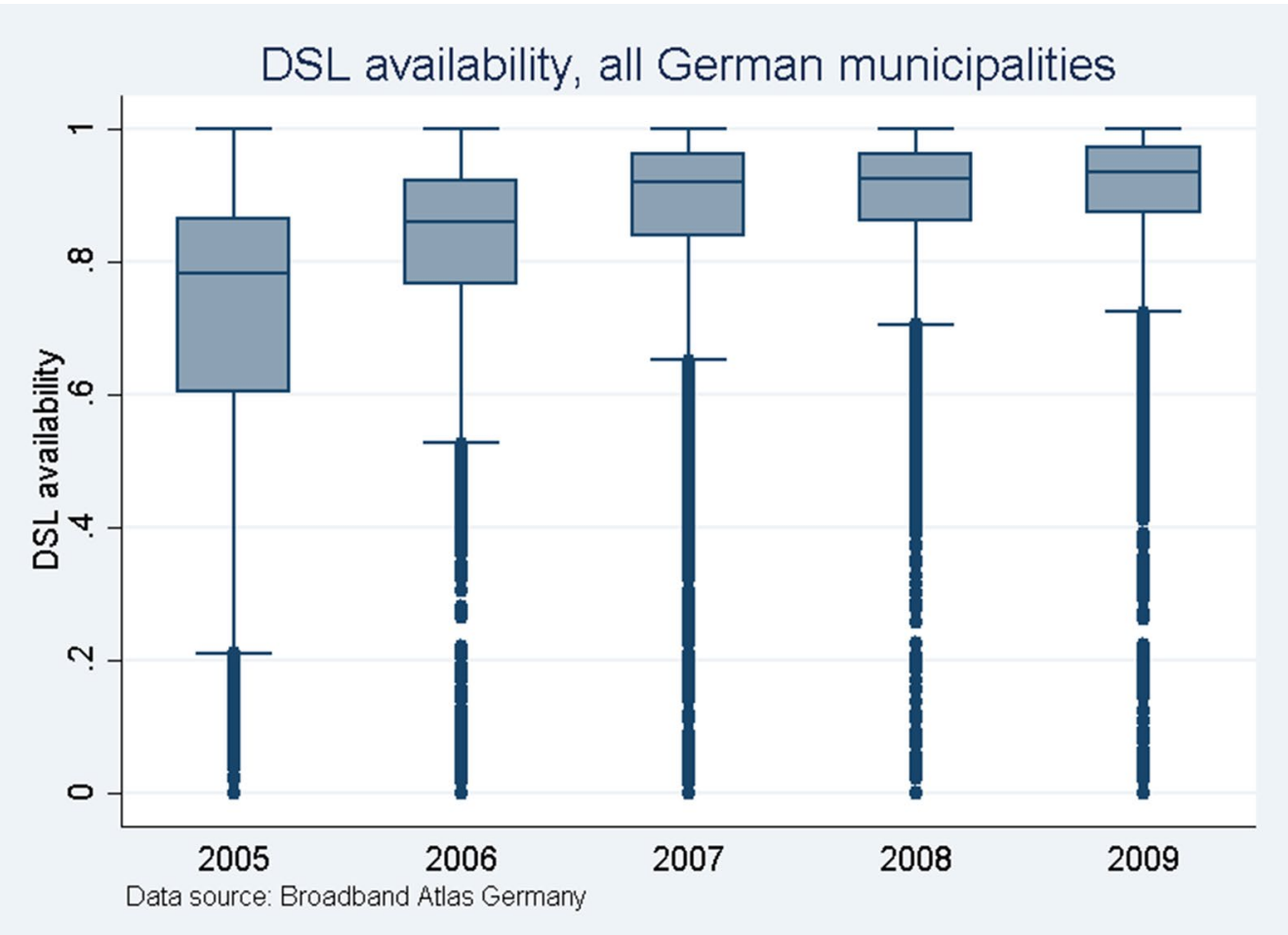

Fig. 4 DSL availability by year, box plot 


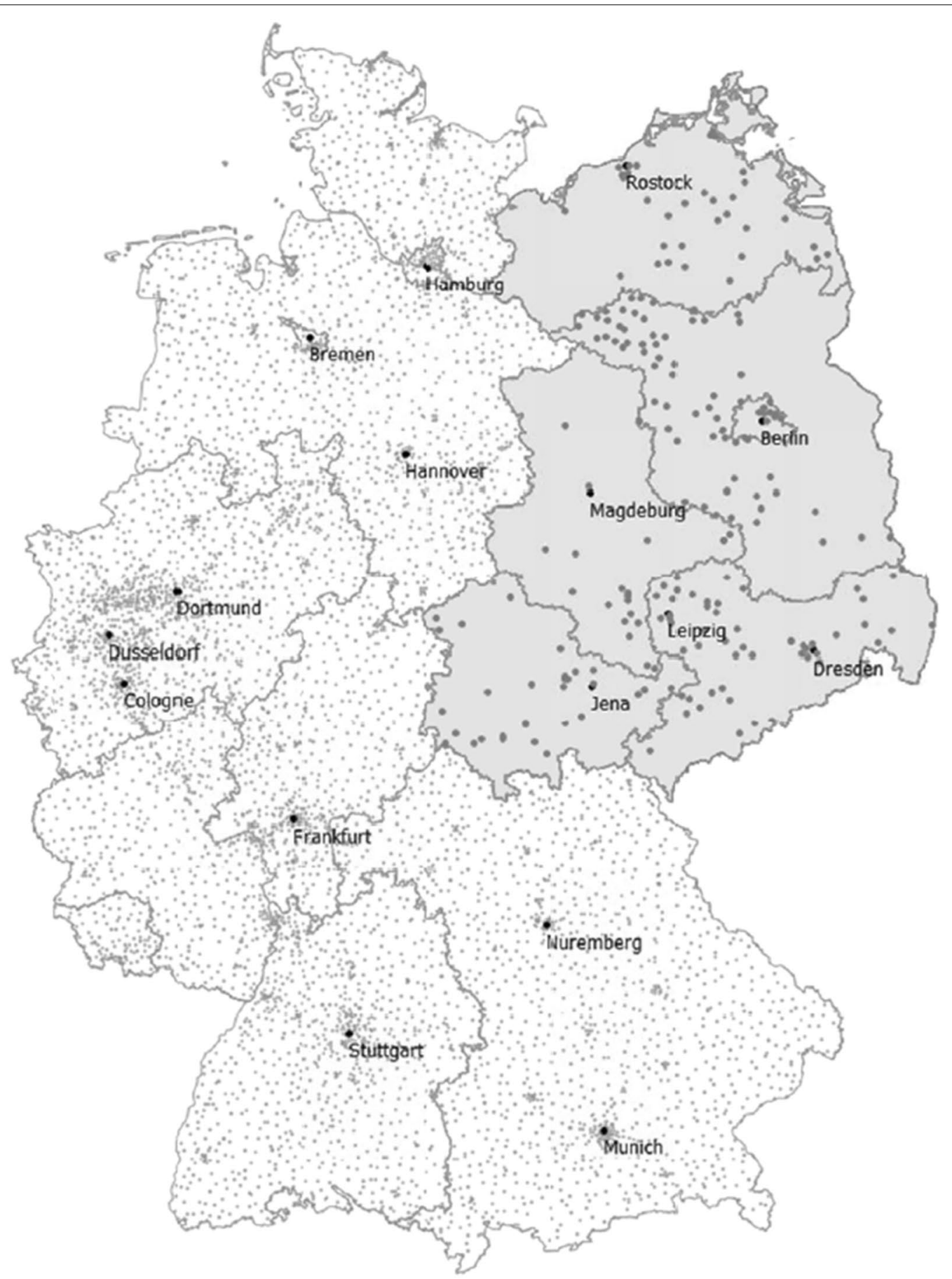

Fig. 5 MDF locations (Western Germany) and OPAL areas (Eastern Germany). Source: Falck et al. (2014), online appendix 


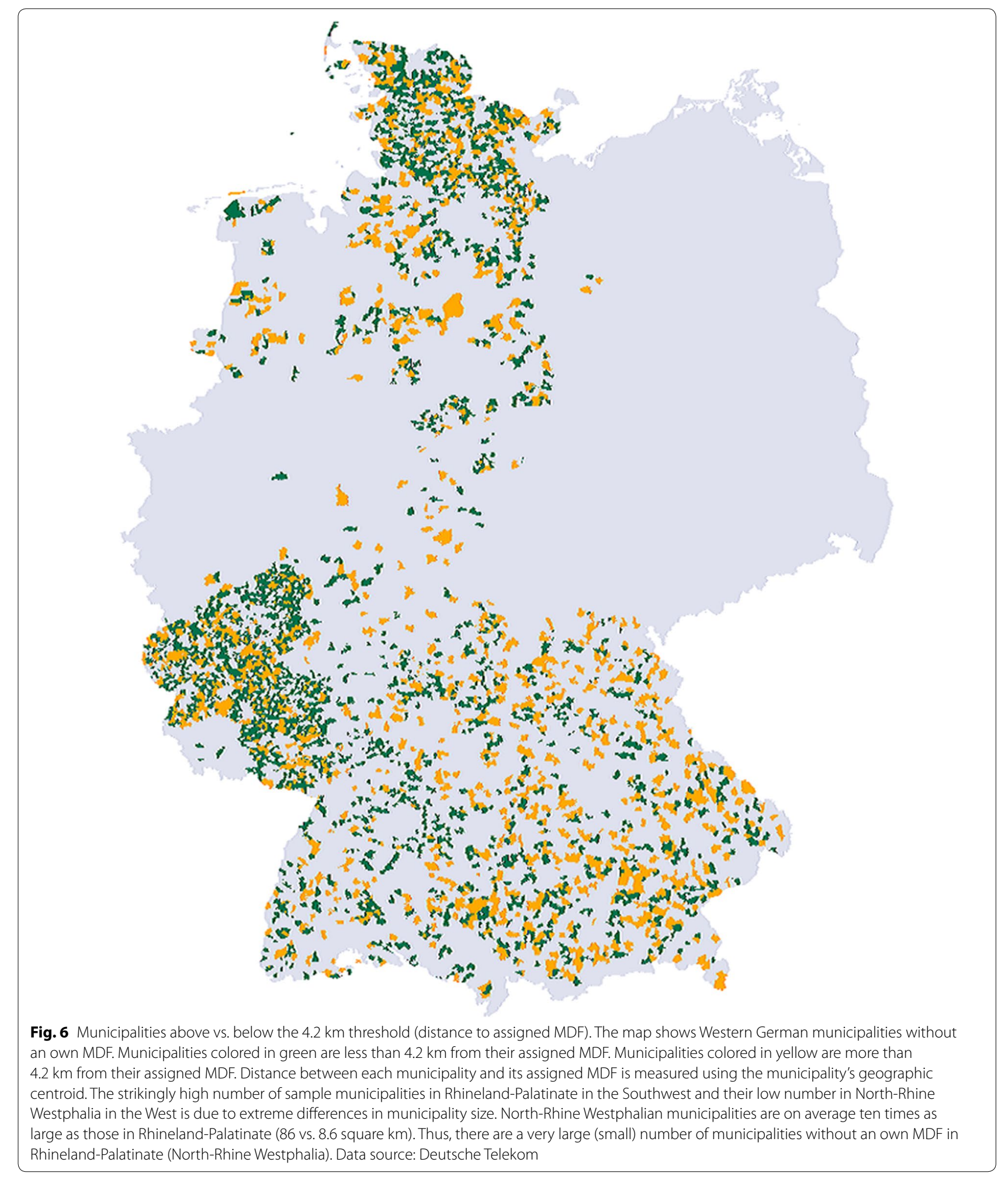


Received: 6 December 2018 Accepted: 9 May 2019

Published online: 16 May 2019

\section{References}

Akerman, A., Gaarder, I., Mogstad, M.: The skill complementarity of broadband internet. Q. J. Econ. 130(4), 1781-1824 (2015)

Angrist, J.D., Pischke, J.S.: Mostly harmless econometrics: an empiricist's companion. Princeton University Press, Princeton (2009)

Arntz, M., Gregory, T., Lehmer, F., Matthes, B., Zierahn, U.: Arbeitswelt 4.0Stand Der Digitalisierung in Deutschland: Dienstleister Haben Die Nase Vorn. IAB-Kurzbericht, 22 (2016)

Atasoy, $\mathrm{H}$.: The effects of broadband internet expansion on labor market outcomes. Ind. Labor Relat. Rev. 66(2), 315-345 (2013)

Atkinson, R.D., McKay, A.S.: Digital prosperity: understanding the economic benefits of the information technology revolution. http://ssrn.com/abstr act $=1004516$ (2007). Accessed 14 May 2019

Autor, D.: Wiring the labor market. J. Econ. Perspect. 15(1), 25-40 (2001)

Bauernschuster, S., Falck, O., Woessmann, L.: Surfing Alone? The internet and social capital: evidence from an unforeseeable Technological Mistake. J. Public Econ. 117, 73-89 (2014)

Bertschek, I., Niebel, T.: Mobile and more productive? Firm-level evidence on the productivity effects of mobile internet use. Telecommun. Policy 40(9), 888-898 (2016)

Bertschek, I., Cerquera, D., Klein, G.: More bits-more bucks? Measuring the impact of broadband internet on firm performance. Inf. Econ. Policy 25(3), 190-203 (2013)

Bertschek, I., Briglauer, W., Hüschelrath, K., Kauf, B., Niebel, T.: The economic impacts of broadband internet: a survey. Rev. Netw. Econ. 14(4), 201-227 (2015)

Billari, F.C., Giuntella, O., Stella, L.: Does broadband internet affect fertility? Popul. Stud. (2019). https://doi.org/10.1080/00324728.2019.1584327

Bresnahan, T., Trajtenberg, M.: General purpose technologies 'engines of growth'? J. Econometr. 65(1), 83-108 (1995)

Brynjolfsson, E., Yu, H., Rahman, M.S.: Battle of the retail channels: how product selection and geography drive cross-channel competition. Manage. Sci. 55(11), 1755-1765 (2009)

Bundesnetzagentur: Annual report 2012. energy, communications, mobility: shaping expansion together. Bonn (2013)

Cahuc, P., Zylberberg, A.: Labor economics. The MIT Press, Cambridge (2004)

Canzian, G., Poy, S., Schüller, S.: Broadband diffusion and firm performance in rural areas: quasi-experimental evidence. IZA Discussion Paper, 9429 (2015)

Cardona, M., Kretschmer, T., Strobel, T.: ICT and productivity: conclusions from the empirical literature. Inf. Econ. Policy 25(3), 109-125 (2013)

Colombo, M.G., Croce, A., Grilli, L.: ICT services and small businesses' productivity gains: an analysis of the adoption of broadband internet technology. Inf. Econ. Policy 25(3), 171-189 (2013)

Czernich, N.: Does broadband internet reduce the unemployment rate? Evidence for Germany. Inf. Econ. Policy 29, 32-45 (2014)

Czernich, N., Falck, O., Kretschmer, T., Woessmann, L.: Broadband infrastructure and economic growth. Econ. J. 121(552), 505-532 (2011)

De Stefano, T., Kneller, R., Timmis, J.: The (fuzzy) digital divide: the effect of broadband internet use on UK firm performance. University of Nottingham Discussion Papers in Economics, (14/06) (2014)

De Stefano, T., Kneller, R., Timmis, J.: Broadband infrastructure, ICT use and firm performance: evidence for UK firms. J. Econ. Behav. Organ. 155, 110-139 (2018)

Dettling, L.J.: Broadband in the labor market: the impact of residential highspeed internet on married women's labor force participation. ILR Rev. 70(2), 451-482 (2017)

Draca, M., Martin, R., Sanchis-Guarner, R.: The evolving role of ICT in the economy. Report by LSE Consulting for Huawei (2018)

Einav, L., Knoepfle, D., Levin, J., Sundaresan, N.: Sales taxes and internet commerce. Am. Econ. Rev. 104(1), 1-26 (2014)

Ellison, G., Ellison, S.F.: Tax sensitivity and home state preferences in internet purchasing. Am. Econ. J.: Econ. Policy 1(2), 53-71 (2009)
Eurostat:: High-Tech Industry and Knowledge-Intensive Services (Htec). Eurostat indicators on High-tech industry and Knowledge-intensive services. http://ec.europa.eu/eurostat/cache/metadata/EN/htec_esms. htm (2016). Accessed 29 Mar 2017

Fabritz, N.: The impact of broadband on economic activity in rural areas: evidence from German municipalities. Ifo Working Paper No. 166 (2013)

Falck, O., Gold, R., Heblich, S.: E-lections: voting behavior and the internet. Am. Econ. Rev. 104(7), 2238-2265 (2014)

Falck, O., Heimisch, A., Wiederhold, S.: Returns to ICT skills. IEB Working Paper N. 2016/05 (2016)

Federal Ministry of Economics and Technology: Broadband Atlas Germany. Berlin (2009)

Federal Ministry of Transport and Digital Infrastructure: Aktuelle Breitbandverfügbarkeit in Deutschland (Stand Mitte 2018). Erhebung des TÜV Rheinland im Auftrag des BMVI (2018)

Forman, C., Goldfarb, A., Greenstein, S.: The internet and local wages: a puzzle. Am. Econ. Rev. 102(1), 556-575 (2012)

Goolsbee, A.: In a world without borders: the impact of taxes on internet commerce* ${ }^{*}$ Q. J. Econ. 115(2), 561-576 (2000)

Goolsbee, A., Lovenheim, M.F., Slemrod, J.: Playing with fire: cigarettes, taxes, and competition from the internet. Am. Econ. J.: Econ. Policy 2(1), 131-154 (2010)

Gruhl, A., Schmucker, A., Seth S.: The establishment history panel 1975-2010. Handbook version 2.2.1. FDZ Datenreport, 04 (en) (2012)

Haller, S.A., Lyons, S.: Effects of broadband availability on total factor productivity in service sector firms: evidence from Ireland. Telecommun. Policy 43(1), 11-22 (2019)

Harris, R.G.: The internet as a GPT: factor market implications. In: Helpman E (ed) General purpose technologies and economic growth, pp. 145-166. MIT Press (1998)

Hausman, J.: Mismeasured variables in econometric analysis: problems from the right and problems from the left. J. Econ. Perspect. 15(4), 57-67 (2001)

Hethey, T., Schmieder, J.F.: Using worker flows in the analysis of establishment turnover-evidence from German administrative data, p. 6. FDZ Methodenreport, IAB, Nuremberg (2010)

Holt, L., Jamison, M.: Broadband and contributions to economic growth: lessons from the Us experience. Telecommun. Policy 33(10), 575-581 (2009)

Imbens, G.W., Angrist, J.D.: Identification and estimation of local average treatment effects. Econometrica 62(2), 467-475 (1994)

Ivus, O., Boland, M.: The Employment and wage impact of broadband deployment in Canada. Can. J. Econ. 48(5), 1803-1830 (2015)

Katz, R., Suter, S.: Estimating the economic impact of the broadband stimulus plan." Columbia institute for tele-information working paper, 7 (2009)

Kolko, J.: Broadband and local growth. J. Urban Econ. 71(1), 100-113 (2012)

Kuhn, P., Mansour, H.: Is internet job search still ineffective? Econ. J. 124(581), 1213-1233 (2014)

Kuhn, P., Skuterud, M.: Internet job search and unemployment durations. American Economic Review 94(1), 218-232 (2004)

Mang, C.: Online job search and matching quality. Ifo Working Paper, 147 (2012)

Stock, J.H., Wright, J.H., Yogo, M.: A survey of weak instruments and weak identification in generalized method of moments. J. Bus. Econ. Stat. 20(4), 518-529 (2002)

What Works Centre for Local Economic Growth: Evidence review 6: Broadband London School of Economics and Political Science, Arup, and Centre for Cities (2015)

Whitacre, B., Gallardo, R., Strover, S.: Broadband's contribution to economic growth in rural areas: moving towards a causal relationship. Telecommun. Policy 38(11), 1011-1023 (2014)

Wooldridge, J.M.: Score diagnostics for linear models estimated by two stage least squares. Advances in econometrics and quantitative economics: essays in honor of Professor CR Rao, 66-87 (1995)

\section{Publisher's Note}

Springer Nature remains neutral with regard to jurisdictional claims in published maps and institutional affiliations. 